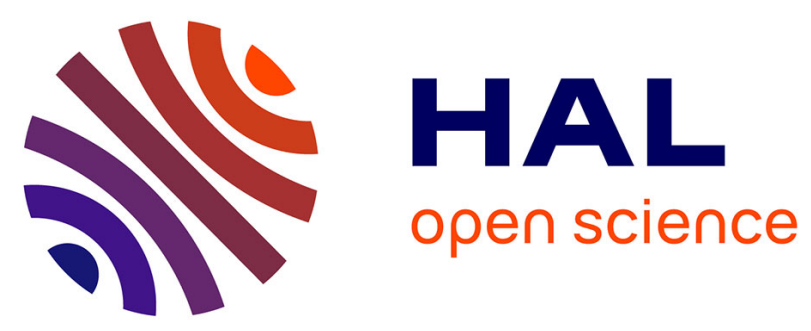

\title{
Early molecular events involved in Pinus pinaster Ait. somatic embryo development under reduced water availability: transcriptomic and proteomic analyses
}

\author{
Alexandre Morel, Caroline Teyssier, Jean-François Trontin, Kateřina Eliášová, \\ Bedřich Pešek, Martine Beaufour, Domenico Morabito, Nathalie Boizot, \\ Claire Le Metté, Leila Belal-Bessai, et al.
}

\section{To cite this version:}

Alexandre Morel, Caroline Teyssier, Jean-François Trontin, Kateřina Eliášová, Bedřich Pešek, et al.. Early molecular events involved in Pinus pinaster Ait. somatic embryo development under reduced water availability: transcriptomic and proteomic analyses. Physiologia Plantarum, 2014, 152 (1), pp.184-201. 10.1111/ppl.12158 . hal-01179486

\author{
HAL Id: hal-01179486 \\ https://hal.science/hal-01179486
}

Submitted on 27 May 2020

HAL is a multi-disciplinary open access archive for the deposit and dissemination of scientific research documents, whether they are published or not. The documents may come from teaching and research institutions in France or abroad, or from public or private research centers.
L'archive ouverte pluridisciplinaire HAL, est destinée au dépôt et à la diffusion de documents scientifiques de niveau recherche, publiés ou non, émanant des établissements d'enseignement et de recherche français ou étrangers, des laboratoires publics ou privés. 
Version définitive du manuscrit publié dans / Final version of the manuscript published in : Physiologia Plantarum, 2014, 152(1), 184-201 http://dx.doi.org/10.1111/ppl.12158

\section{Physiologia \\ Plantarum}

\section{Early molecular events involved in Pinus pinaster Ait. somatic embryo development under reduced water availability: transcriptomic and proteomic analyses.}

\begin{tabular}{|c|c|}
\hline Journal: & Physiologia Plantarum \\
\hline Manuscript ID: & PPL-2013-00496.R1 \\
\hline Manuscript Type: & Regular manuscript - Development, growth and differentiation \\
\hline Date Submitted by the Author: & $\mathrm{n} / \mathrm{a}$ \\
\hline Complete List of Authors: & $\begin{array}{l}\text { Lelu-Walter, M.-A.; INRA, } \\
\text { MOREL, Alexandre; INRA, UR } 0588 \text { AGPF } \\
\text { Teyssier, Caroline; INRA, Unit for Breeding, Genetics and Physiology of } \\
\text { Forest trees } \\
\text { Trontin, Jean-Francois; FCBA, } \\
\text { Eliášová, Kateřina; Institute of Experimental Botany, ASCR } \\
\text { Pešek, Bedřich; Institute of Experimental Botany, ASCR } \\
\text { Beaufour, Martine; CNRS, } \\
\text { Morabito, Domenico; Univ Orleans, UFR Fac Sci } \\
\text { BOIZOT, Nathalie; INRA, UR 0588 AGPF } \\
\text { REYMOND, Isabelle; FCBA, } \\
\text { HARVENGT, Luc; FCBA, } \\
\text { CADENE, Martine; CNRS, } \\
\text { Corbineau, Françoise; UPMC, } \\
\text { Vagner, Martin; Institute of Experimental Botany, ASCR } \\
\text { Label, Philippe; INRA, UMR_A } 547 \text { PIAF }\end{array}$ \\
\hline Key Words: & $\begin{array}{l}\text { somatic embryo development, germin-like protein, glycolysis, protein } \\
\text { phosphatase } 2 \text { C, ubiquitin-protein ligase }\end{array}$ \\
\hline
\end{tabular}


Version définitive du manuscrit publié dans / Final version of the manuscript published in :

Physiologia Plantarum, 2014, 152(1), 184-201 http://dx.doi.org/10.1111/ppl.12158

1 Early molecular events involved in Pinus pinaster Ait. somatic embryo development under 2 reduced water availability: transcriptomic and proteomic analyses.

3

4 Alexandre Morel $^{1}$, Caroline Teyssier ${ }^{1}$, Jean-François Trontin ${ }^{2}$, Kateřina Eliášováa ${ }^{3}$, Bedřich Pešek ${ }^{3}$,

5 Martine Beaufour ${ }^{4}$, Domenico Morabito ${ }^{5}$, Nathalie Boizot ${ }^{1}$, Claire Le Metté ${ }^{1}$, Leila Belal-Bessai ${ }^{1}$,

6 Isabelle Reymond ${ }^{2}$, Luc Harvengt ${ }^{2}$, Martine Cadene ${ }^{4}$, Françoise Corbineau ${ }^{6}$, Martin Vágner $^{3}$, Philippe

7 Label $^{1} \dagger^{* *}$, Marie-Anne Lelu-Walter ${ }^{1} \dagger^{*}$

8

9 1: INRA, UR 0588 Unité Amélioration, Génétique et Physiologie Forestières, 2163 Avenue de la 10 Pomme de Pin, CS 4001, Ardon, F-45075 Orléans Cedex 2, France

112 : FCBA, Pôle Biotechnologie et Sylviculture Avancée, Equipe Génétique et Biotechnologie, Campus 12 Forêt-Bois de Pierroton, 71 route d'Arcachon, F-33610 Cestas, France.

133 : Institute of Experimental Botany ASCR, Rozvojová 263, Praha 6-Lysolaje, 165 02, Czech 14 Republic.

154 : CNRS, UPR4301, Centre de Biophysique Moléculaire, Rue Charles Sadron, F-45100 Orléans, 16 France.

17 5: Univ. Orléans, INRA, LBLGC, EA1207, F-45067, Orléans, France

18 6: Sorbonne Universités, UPMC Univ Paris 06, UMR 7622, Biologie du Développement, 4 place 19 Jussieu, F-75005, Paris, France.

$\dagger$ These authors contributed equally to this work

22

* Corresponding author: Marie-Anne Lelu-Walter

24

Phone : +33 (0) 238417800

25

Fax : $+33(0) 238417879$

26

e-mail : marie-anne.lelu-walter@orleans.inra.fr 
Version définitive du manuscrit publié dans / Final version of the manuscript published in : Physiologia Plantarum, 2014, 152(1), 184-201 http://dx.doi.org/10.1111/ppl.12158

Summary

1 Summary

2 Maritime pine somatic embryos require a reduction in water availability (high gellan gum

3 concentration in the maturation medium) to reach the cotyledonary stage. This key switch, reported

4 specifically for pine species, is not yet well understood. To facilitate the use of somatic embryogenesis

5 for mass propagation of conifers, we need a better understanding of embryo development. Comparison

6 of both transcriptome (Illumina RNA sequencing) and proteome (2D-SDS-PAGE with MS

7 identification) of immature somatic embryos, cultured on either high $(9 \mathrm{G})$ or low (4G) gellan gum

8 concentration, was performed, together with analysis of water content, fresh and dry mass,

9 endogenous ABA (GC-MS), soluble sugars (HPLC), starch, and confocal laser microscope

10 observations. This multi-scale, integrated analysis was used to unravel early molecular and

11 physiological events involved in somatic embryo development. Under unfavourable conditions (4G),

12 the glycolytic pathway was enhanced, possibly in relation to cell proliferation which may be

13 antagonistic to somatic embryo development. Under favourable conditions (9G), somatic embryos

14 adapted to culture constraint by activating specific protective pathways, and ABA-mediated molecular

15 and physiological responses promoting embryo development. Our results suggest that on 9G, germin-

16 like protein and ubiquitin-protein ligase could be used as predictive markers of somatic embryo

17 development whereas protein phosphatase $2 \mathrm{C}$ could be a biomarker for culture adaptive responses.

18 This is the first characterization of early molecular mechanisms involved in development of pine

19 somatic embryos following an increase in gellan gum concentration in the maturation medium, and it

20 is also the first report on somatic embryogenesis in conifers combining transcriptomic and proteomic 21 datasets.

22

23

24

25

26

27

28

\section{Abbreviations}

ABA, abscisic acid ; EMs, embryonal masses; SE, somatic embryo. 
Version définitive du manuscrit publié dans / Final version of the manuscript published in : Physiologia Plantarum, 2014, 152(1), 184-201 http://dx.doi.org/10.1111/ppl.12158

\section{Introduction}

2 Maritime pine, Pinus pinaster Ait., is industrially important in South-Western Europe, especially in

3 France, Portugal and Spain. Maintenance of plantation productivity, together with increasing forest

4 resilience to major biotic and abiotic risks, are thus major objectives for this species. In order to

5 bypass the current limitations of classical methods for accelerating tree domestication, technological

6 innovation is required, and this may result from any of a number of biotechnological inputs into

7 improvement programs (Harfouche et al. 2012).

8 Biotechnology offers new opportunities for improving selection efficiency (balancing genetic gain and

9 genetic diversity), conservation and deployment of new varieties for reforestation. As a high-

10 performance, clonal propagation system, somatic embryogenesis is a powerful tool for scaling up

11 production of genetically improved varieties (Park, 2002). During the last decade, methodology for

12 somatic embryogenesis in conifers has undergone rapid and significant progress (see review Lelu-

13 Walter et al. 2013). However, somatic embryo (SE) maturation a challenging step (Stasolla et al.

14 2002) towards rapid production of uniform and consistent emblings quality up to the accepted standard

15 by foresters for conventional seedlings in commercial deployment of new varieties. Since the early

16 protocols were developed for spruce species (Attree and Fowke, 1993), it was assumed that they

17 would be applicable to pines; however, it subsequently became apparent that pines were less

18 responsive to these approaches. When effective, somatic embryogenesis could also result in qualitative

19 and quantitative differences in gene expression between somatic and reference zygotic embryos (Lara-

20 Chavez et al. 2012; Pérez Rodríguez et al. 2006). Such distinctive features raised the important

21 question of achieving in pine similar SE development to high-quality seedlings.

22 With regard to zygotic embryogenesis, the genus Pinus differs markedly from Picea, the main 23 difference in Pinus being the type of cleavage that takes place at the late embryogeny stage (Dogra, 24 1978). In pine somatic embryogenesis, recovery of cotyledonary SE occurs only if the availability of 25 water to the embryonal masses is reduced (Klimaszewska and Smith, 1997). This is achieved by 26 increasing the gel strength of the medium, by using a high gellan gum concentration (Klimaszewska et 27 al. 2000). In maritime pine, SE maturation, which is a protracted process (requiring 12 weeks to reach 28 the cotyledonary stage), is obtained only on high gellan gum concentration, i.e. 9-10 $\mathrm{g} \mathrm{L}^{-1}$ 29 (Ramarosandratana et al. 2001; Lelu-Walter et al. 2006). In contrast, under low gellan gum 30 concentrations, e.g. $4 \mathrm{~g} \mathrm{~L}^{-1}$ as used for spruce species, embryonal masses undergo excessive 31 proliferation which interferes with embryo maturation.

32 In both angiosperms (Black, 1991) and gymnosperms (Kong et al. 1997), abscisic acid (ABA) is 33 involved in embryogenesis. Apart from certain species such as Pinus taeda (Kapik et al. 1995), ABA 34 content increases during seed maturation, reaches a maximum and then declines as the seed dehydrates 35 (reviewed by King, 1982). In Picea glauca the main source of ABA for the developing zygotic 36 embryo is from the surrounding tissue, the megagametophyte (Kong et al. 1997). Interestingly, for 37 conifers exogenous ABA promotes SE maturation through accumulation of storage products such as 
1 proteins (Gutmann et al. 1996). ABA can regulate the switch from embryonal mass proliferation to

2 embryo development (Stasolla et al. 2002).

3 Many stress treatments, such as water stress, are known to induce de novo synthesis of ABA and 4 therefore to enhance endogenous ABA levels. These increases generally occur during the first days of 5 the treatment. Desiccation of hybrid larch SE was found to result in reduced water content associated 6 with a transient increase in ABA (Dronne et al. 1997). ABA signaling involves complex transduction 7 mechanisms in which there is cross-talk between serine/threonine kinase (SRK2) and protein 8 phosphatase 2C (PP2C) during ontogenesis (Umezawa et al. 2009).

9 In addition to water availability and ABA, carbohydrate supply is of great importance for pine somatic embryogenesis. In Pinus pinaster, maturation of SE is enhanced by raising the sucrose concentration to $0.2 \mathrm{M}$ (Lelu-Walter et al. 2006). Clearly, endogenous carbohydrate status varies throughout somatic embryogenesis (see review by Lipavská and Konrádová, 2004). In general, during the proliferation phase embryonal masses have a high hexose content and almost no sucrose, resulting in a high hexose/sucrose ratio. On the other hand, maturation results in a decrease in hexose content whereas a gradual increase in sucrose content is observed in the SE (Lipavská et al. 2000). Starch, accumulates mainly during the first weeks of the maturation process.

In addition to these physiological studies, efforts have recently been made to describe SE development in conifers at the molecular level, but studies so far remain limited. Proteomic studies, combining 2Dgel electrophoresis with a high degree of accuracy in protein identification by mass spectrometry, are available only for Cupressus sempervirens (Sallandrouze et al. 1999), Picea glanca (Lippert et al. 2005), and Larix x eurolepis (Teyssier et al. 2013). These studies have contributed to the identification of proteins involved in the embryogenesis process. For gene expression, only a few reports are available, mainly for Picea abies. In this species, transcript levels have been compared between different lines (embryogenic vs developmentally arrested) at different SE developmental stages (Stasolla et al. 2004). More recently, changes in expression of genes with products, involved in auxin biosynthesis and gibberellin-mediated signaling were reported, in a study that made the assumption that conifer genes are homologous to those in Arabidopsis (Vestman et al. 2011). In support of this assumption, genes related to embryogenesis in model plants have sequence similarity to expressed sequence tags (ESTs) from Pinus taeda and Larix leptolepis (Cairney and Pullman, 2007; Zhang et al. 2012).

This study provides new insights into early molecular events regulating the development of Pinus pinaster SE under reduced water availability. Our original approach consists in integrated multi-scale analyses, including comparisons of the transcriptome and proteome with histological, biological and biochemical observations. This is the first report combining transcriptomic and proteomic data for conifers somatic embryogenesis. The molecular mechanisms underlying SE response to reduced water availability are discussed in detail. We have found novel candidate predictive markers for conifer SE development as well as for adaptive responses, which will facilitate practical application of the 


\section{Version définitive du manuscrit publié dans / Final version of the manuscript published in :} Physiologia Plantarum, 2014, 152(1), 184-201 http://dx.doi.org/10.1111/ppl.12158

1 knowledge gained in this study to monitor early responses of embryogenic tissue to maturation

2 conditions.

3

4 Material and Methods

\section{$5 \quad$ Pinus pinaster somatic embryogenesis}

6 Experiments were conducted with an embryogenic line (AAY06006) of Pinus pinaster. Embryonal 7 Masses (EMs) were initiated from immature zygotic embryos (Park et al. 2006) originating from a 8 Landes x Morocco polycross. EMs were subcultured and matured in darkness according to Lelu9 Walter et al. (2006). Briefly, filter paper discs with dissociated EMs were transferred onto maturation medium which consisted of modified Litvay medium (Litvay et al. 1985) supplemented with $0.2 \mathrm{M}$ sucrose, $80 \mu \mathrm{M}$ cis-trans $\left( \pm\right.$ ) abscisic acid (ABA, Sigma) and either $4 \mathrm{~g}$ or $9 \mathrm{~g} \mathrm{~L}^{-1}$ gellan gum 12 (Phytagel ${ }^{\mathrm{TM}}$ Sigma), indicated here as $4 \mathrm{G}$ and $9 \mathrm{G}$ respectively. After 12 weeks of maturation, cotyledonary SE were counted and embryogenic potential (number of SE per g FW) was estimated.

\section{Fresh Weight (FW), Dry Weight (DW), and water content of EMs}

Measurements were performed after 0,1,2,3 and 4 weeks of maturation on both media. Each week, each filter paper disc with dispersed EMs was weighed and replaced on the maturation medium. FW of EMs was obtained by subtracting the mass of the filter paper disc from the total FW. DW was determined after oven-drying at $70^{\circ} \mathrm{C}$ for $24 \mathrm{~h}$ and calculated by multiplying the DW to FW ratio by 100 (Teyssier et al. 2011). Water content was calculated as (FW-DW)/DW and expressed as $\mathrm{g}_{2} \mathrm{O} \mathrm{g} \mathrm{g}^{-1}$ DW (Dronne et al. 1997). Finally, water availability from the maturation media was determined by measuring the amount of water absorbed by the filter paper disc (Teyssier et al. 2011). Each assay (FW, DW, water content, water availability) was carried out on ten biological replicates for each medium at each time point.

\section{Histology and microscopy}

EMs were collected after 0, 1, 2 and 3 weeks of maturation on both media. EM viability was determined by double staining with fluorescein diacetate (FDA) (Sigma-Aldrich) and propidium iodide (PI) (Sigma-Aldrich) according to modified protocols (Jones and Senft, 1985; Petřek et al. 2005; Vondráková et al. 2010). A LSM5 Duo confocal laser scanning microscope (Zeiss, Jena, Germany) equipped with an Argon/2 laser (FDA excitation at $488 \mathrm{~nm}$, emission filter-set BP 505-550) and a DPSS laser (PI excitation at $561 \mathrm{~nm}$, emission filter-set LP 650) was used to visualize stained EMs. Viable cells exhibit bright green fluorescence, non-viable or dead cells show bright red fluorescence. Starch grains in squashed fresh EMs were stained with iodine/potassium iodide and observed with a Jenaval transmission light microscope (Zeiss, Jena, Germany) equipped with a DS-

$365 \mathrm{M}$ digital camera (Nikon, Tokyo, Japan). All images were processed using the computer image 37 analysis system NIS Elements, version 3.2 (Laboratory Imaging, Prague, Czech Republic). 
Version définitive du manuscrit publié dans / Final version of the manuscript published in : Physiologia Plantarum, 2014, 152(1), 184-201 http://dx.doi.org/10.1111/ppl.12158

2 ABA and abscisic acid glucose ester (ABA-GE) measurements.

3 Sample preparation and determination of $A B A$ and $A B A-G E$. EMs were collected after 0, 1, 2, 3 and 4 4 weeks of maturation. Samples (each approximately $0.5 \mathrm{~g} \mathrm{FW}$ ) were ground to powder in liquid 5 nitrogen using a pestle and mortar, and each sample was mixed with $3 \mathrm{~mL}$ of modified Bieleski 6 solution; a further $2 \times 3 \mathrm{~mL}$ of the solution was used to rinse the mortar and the three extracts were 7 combined. ABA and ABA-GE labeled with stable isotopes were added to the extraction mixture as 8 internal standards and the mixture was left overnight to extract. The extract was centrifuged and 9 applied on C18 SPE column (Strata C18-T, Grace, U.S.A.) to eliminate non-polar compounds. The eluate was partly evaporated by the rotary vacuum evaporator (RVE) to approx. $3 \mathrm{~mL}$ and acidified by adding of $1 \mathrm{~mL}$ of $1 \mathrm{M}$ formic acid. The eluate was applied on the MCX SPE column (Oasis MCX, Waters, U.S.A.), cleaned by $2 \mathrm{~mL}$ of $1 \mathrm{M}$ formic acid, then eluted by $5 \mathrm{~mL}$ of $100 \%$ methanol and evaporated on the rotary vacuum concentrator to dryness. Dried samples were diluted in $100 \mu \mathrm{l}$ of $15 \%$ (v/v acetonitrile:water) solution and filtered on Nylon $0.2 \mu \mathrm{m}$ Micro-Spin (Grace, USA) filters. The filtrates were divided into two parts, one for determination of $\mathrm{ABA}$, the second for determination of ABA-GE.

ABA determination by GC-MS. ABA was analyzed by GC-MS/MS (Vandenbusche et al., 2010). The MS detector (ion-trap) was operated in MS/MS mode: MS/MS precursor 190.2, product full scan 65$200 \mathrm{amu}$ for ABA; MS/MS precursor 194.2, product full scan 70-200 amu for labeled ABA. At the first stage, MS full scan 50-300 amu was added to confirm the identity of the substance. A calibration graph for each substance was constructed to cover the range 1-1000 ng mL-1 of final extract. ABA-GE determination by $L C-M S$. A $5 \mu \mathrm{L}$ sample of filtrate was injected into an LC-MS system consisting of an HTS PAL autosampler (CTC Analytics, Switzerland), Rheos 2200 gradient HPLC pump (Flux, Switzerland) and Quantum Ultra AM triple-quadrupole mass spectrometer (Thermo Instruments, USA) equipped with an ESI interface. Separation was performed on an HPLC column, 50 x $2.1 \mathrm{~mm}$ Kinetex C18 (Phenomenex, USA) using gradient elution with a mobile phase consisting of acetonitrile, water and 1\% acetic acid. The mass spectrometer was set to record SRM transitions $425 \rightarrow 153$ for ABA-GE and, as internal standard, $430 \rightarrow 157$ for D5-ABA-GE. A calibration graph was constructed to cover the concentration range 1-100 ng mL-1 of extract.

\section{Determination of carbohydrate and total protein content}

Maturation was performed as described above and EMs were collected after 1 week. Carbohydrate and starch assay. Soluble sugars were extracted as described by Black et al. (1996). EMs (approximately $40 \mathrm{mg} \mathrm{FW}$ ) were ground in $1 \mathrm{~mL} \mathrm{80 \%} \mathrm{aqueous} \mathrm{ethanol} \mathrm{containing} \mathrm{melezitose} \mathrm{as}$ an internal standard and lipids were removed using chloroform $(1: 1, \mathrm{v} / \mathrm{v})$. An aliquot of the aqueous phase was freeze-dried and the dried extract was dissolved in distilled water, filtered through a 0.45 


\section{Version définitive du manuscrit publié dans / Final version of the manuscript published in : Physiologia Plantarum, 2014, 152(1), 184-201 http://dx.doi.org/10.1111/ppl.12158}

$180: 20(\mathrm{v} / \mathrm{v})$ acetonitrile/ $\mathrm{H}_{2} \mathrm{O}$ at a flow rate of $1 \mathrm{~mL} \mathrm{~min}^{-1}$ on a $200 \times 4.6 \mathrm{~mm}$ Spherisorb-NH2 column 2 (Thermo Fisher Scientific, France). The eluates were analyzed with a differential refractometer (RI

3 Plus Detector, Thermo Fisher Scientific, France) and the peak areas were electronically integrated 4 using ChromQuest 5.0 (Thermo Fisher Scientific, France). The various sugars were identified by co5 elution with standards (Sigma, St Louis, MO, USA). For starch, undissolved sample pellets resulting 6 from soluble carbohydrate extraction were dried and incubated in $0.02 \mathrm{~N} \mathrm{NaOH}$ for $2 \mathrm{~h}$ at $95^{\circ} \mathrm{C}$. After 7 cooling to room temperature, starch was reduced to glucose: amyloglucosidase (35 U) was added and 8 samples were incubated at $50^{\circ} \mathrm{C}$ for $1 \mathrm{~h}$ with stirring. After centrifugation, aliquots of the clear 9 supernatants were assayed for glucose (Bergmeyer et al. 1974).

Total protein assay. Total protein extracts were prepared from five replicates for each type of sample (25 to $50 \mathrm{mg} \mathrm{FW}$ of frozen EMs) as previously described (Teyssier et al. 2013). Protein concentrations

\section{Transcriptomic analysis}

Maturation was carried out as described above. EMs were collected after 1 week of maturation on $4 \mathrm{G}$ and $9 \mathrm{G}$, frozen in liquid nitrogen, and ground for 5 min with a mortar and pestle to a fine powder. Frozen powder samples were divided into two equal portions (each about $400 \mathrm{mg} \mathrm{FW}$ ) for transcriptomic and proteomic analyses. For transcriptomic analysis, three biological replicates were sampled for each maturation conditions, producing a total of 6 samples.

Sequencing. Library construction and sequencing was done by a commercial service provider (GATC Biotech, Germany). Total RNA was extracted, mRNAs purified and cDNA synthesized according to the Smart Kit (Clontech, USA) manufacturer's recommendations. The six samples were paired-end sequenced on an Illumina Genome Analyser II producing 100 bp paired-end short reads. Primeradapter removal, quality filtering and ambiguous base trimming produced sequences $82 \pm 6$ bp long. The six samples each produced 5,586,402 $\pm 1,514,289$ paired-end sequence pairs, giving a total of 33,518,411 paired-end sequence pairs. Original data were deposited in the NCBI' Sequence Read Archive under accession number SRR609713.

Sequences (termed reference sequences) used for functional annotation and Gene Ontology analysis were from the Pine3 (http://genotoulcontigbrowser.toulouse.inra.fr:9092/Pinus_pinaster3/index.html) also used for mapping the illumina reads. Seventy six percent of our Illumina reads mapped onto these reference sequences. Reference sequences numbered 212,928, N50 was $691 \mathrm{bp}$ and average length was $818 \mathrm{bp}$.

Functional Characterization and Gene Ontology (GO) Annotation. Gene Ontology (GO) annotations to retrieve molecular function, biological process and cellular component terms were performed using Blast2GO (http://www.blast2go.org/) (Conesa et al. 2005). The sequences were loaded into the 
Version définitive du manuscrit publié dans / Final version of the manuscript published in : Physiologia Plantarum, 2014, 152(1), 184-201 http://dx.doi.org/10.1111/ppl.12158

1 Blast2GO program, and BLASTx with a minimum E-value of 1.0 was performed by the program prior

2 to mapping. The mapping step was used to annotate the sequences with GO terms from the GO

3 database. Fisher's exact test was performed within Blast2GO to determine whether GO identifiers

4 occurred more often in a group than would appear by chance. For GO analysis, biological process GO

5 identifiers were considered only if they occurred more than 5 times.

6 Functional Classification by KEGG. Annotation against the Kyoto Encyclopedia of Genes and

7 Genomes (KEGG) database (http://www.genome.jp/kegg/) was performed in order to exploit enzyme

8 data to integrate genomic, chemical and network information (Ogata et al. 1999) using the Blast2GO

9 program. All mapped sequences were annotated to KEGG database accessions to obtain their enzyme

10 commission (EC) numbers. The EC numbers were then mapped onto KEGG to obtain the 11 corresponding KEGG Pathway-Maps.

\section{2-D gel proteomic analysis}

14 2-D PAGE. Total protein extracts were prepared from 5 replicates for each type of sample 15 (approximately $400 \mathrm{mg} \mathrm{FW}$ ) as previously described in Teyssier et al. (2013). Briefly, extraction was 16 realised with phenol and precipitation with ammonium acetate in ethanol then the proteins assayed. 17 First dimension separation was performed with $300 \mu \mathrm{g}$ protein loaded onto $24-\mathrm{cm}$ IPG strips, $\mathrm{pH}$ 4-7 18 (Protean IEF Cell system, BioRad, France), whereas the 2-D PAGE was performed with 11\% 19 polyacrylamide gels. Gels were stained with colloidal CBB-G. The numerical analyse of the gels was 20 performed with Progenesis software (Nonlinear Dynamics, United Kingdom) as described in Teyssier 21 et al. (2013).

22 Gel spot processing. The destain, wash and proteolysis steps and sample preparation for mass 23 spectrometry are described elsewhere (Teyssier et al. 2013).

24 NanoLC-MS/MS analysis. Liquid chromatographic separations of peptides were performed using an 25 UltiMate 3000 nano-ultraLC system (Dionex, USA) after preconcentration on a $15 \mathrm{~cm}$ reverse-phase 26 column (Acclaim Pepmap RSLC C18). Online analysis via a distal-coated PicoTip emitter (New 27 Objective, USA) and a nanospray source was performed on an HCT Ultra ion trap (Bruker, Germany), 28 using HyStar 3.2 software (Bruker) for integration of liquid chromatography and mass spectrometry. 29 The spray voltage was set between 1800 and $2200 \mathrm{~V}$ through EsquireControl 6.2 (Bruker) and the ion 30 trap was scanned in MS mode from m/z 100 to 1500. Peaks with the four highest intensities were selected for CID MS/MS fragmentation within a 4 Da isolation window, using an exclusion $\mathrm{m} / \mathrm{z}$ list and dynamic exclusion as previously described (Beaufour et al. 2012). Fragment ions were scanned from $\mathrm{m} / \mathrm{z} 100$ to 3000 .

34 Protein identification by database sequence assignment. The procedure was as described elsewhere 35 (Teyssier et al. 2013), except for the database used. MS/MS spectra were searched against the Pinus 36 pinaster contig database (see following paragraph). Only proteins with a minimum of four peptides 37 reaching individual scores greater than $60 \%$ were taken into account. Protein lists for each spot were 
Version définitive du manuscrit publié dans / Final version of the manuscript published in : Physiologia Plantarum, 2014, 152(1), 184-201 http://dx.doi.org/10.1111/ppl.12158

1 curated manually to remove redundancies. The false discovery rate (FDR) at the peptide level was 2 calculated by combining all data and applying the decoy feature of the identification engine. A FDR 3 value of $0.57 \%$ was found for peptide scores equal or greater than $60 \%$.

\section{$5 \quad$ Statistical analysis}

6 Statistical analysis was carried out with R software (version 2.8.0; R Development Core Team, 2011). 7 Effects of the treatments on the FW, DW, water content, sugar analysis, total protein analysis and 8 ABA measurements were evaluated using one-way ANOVA. Variations in these parameters during 9 maturation in relation to the gellan gum concentration in the medium were analysed with multiple comparisons of means with Tukey contrasts $(P<0.05)$. For analysis of transcriptomic data, each paired-end sequence was mapped onto the Pinus pinaster transcriptome assembly (http://genotoulcontigbrowser.toulouse.inra.fr:9092/Pinus_pinaster3/index.html) with BWA (Li and Durbin, 2009). Paired-end matches per transcript were counted, and corrected for transcript length and sample sequencing depth to produce transcript expression levels in FPKM (Roberts et al. 2011). Differential expression was assessed by a $t$-test using biological replicates of each treatment. $P$-values were adjusted for multiple hypothesis testing by the Benjamini-Hochberg correction (Benjamini and Hochberg, 1995) to control for the false discovery rate. Transcripts with an adjusted $P$-value below 0.05 were considered to be differentially expressed. Finally, for 2-D PAGE analysis, the intensity change for each spot was analysed with Student's $t$-test on the basis of the normalized spot volume $(P<$ $0.05)$.

\section{Results}

\section{Histological and biological characteristics of maritime pine EMs}

EMs from proliferation medium consisted of single early SEs each being composed of several meristematic cells and a few voluminous suspensor cells with starch grains present (Fig. 1a). After transfer onto 4G maturation medium, embryos started to develop; however, after 2 weeks dead cells were detected in meristematic centres (Fig. 1b). In the third week, dying or dead cells were observed in the majority of suspensors (Fig. 1c). On 9G, meristematic centres gradually enlarged, and suspensors became well organized, comprising a number of long narrow cells after 3 weeks (Fig 1d). Vital staining showed that dead cells were mainly confined to very distal parts of suspensors. A difference in starch grain distribution was clear after 2 weeks of maturation. On 4G, starch grains spread throughout the suspensors and there were a few in basal parts of meristems (Fig. 1e). On 9G, starch grains accumulated to a noticeably higher extent in suspensors and parts of meristems (Fig. 1f). After 12 weeks, EMs on 4G showed overgrowth all over the filters but no embryos (Fig. 2a), whereas those on 9G yielded cotyledonary SE (Fig 2b), the embryogenic potential being estimated at $191 \pm 23$ (mean $\pm \mathrm{CI}$ at the $5 \%$ error level). 
Version définitive du manuscrit publié dans / Final version of the manuscript published in : Physiologia Plantarum, 2014, 152(1), 184-201 $\quad$ http://dx.doi.org/10.1111/ppl.12158

1 Compared with EMs matured on $4 \mathrm{G}$, those transferred onto $9 \mathrm{G}$ showed no FW increase (Fig. 3A), but 2 there was a significant increase in their DW $(P<0.05$, Fig. 3B) and decrease in their water content $(P<$ 30.05 , Fig. 3C). After 4 weeks, EMs matured on $9 \mathrm{G}$ had a significantly higher DW content (10.1\% FW) 4 and lower water content $\left(9.0 \mathrm{~g} \mathrm{H}_{2} \mathrm{O} \mathrm{g}^{-1} \mathrm{DW}\right)$ than those on $4 \mathrm{G}\left(5.1 \% \mathrm{FW}\right.$, and $19.0 \mathrm{~g} \mathrm{H}_{2} \mathrm{O} \mathrm{g}^{-1} \mathrm{DW}$; 5 Fig. 3B, 3C respectively). Availability of water from the maturation medium was significantly lower 6 on $9 \mathrm{G}\left(0.580 \mathrm{~g} \mathrm{H}_{2} \mathrm{O} \pm 0.009\right.$, mean $\pm \mathrm{CI}$ at the $5 \%$ error level. $)$ than on $4 \mathrm{G}\left(0.635 \mathrm{~g} \mathrm{H}_{2} \mathrm{O} \pm 0.008\right)$.

\section{ABA content}

9 At the beginning of the maturation period, the ABA content of EMs was low (2.1 nmol g-1 DW). EMs subsequently showed a significant increase in endogenous ABA (Fig. 4) whereas ABA glucose ester conjugate (ABA-GE) remained undetectable whatever the conditions tested (data not shown). On 9G, ABA content increased slowly during the 3 first weeks of maturation but peaked at $21.1 \mathrm{nmol} \mathrm{g}^{-1} \mathrm{DW}$ after 4 weeks. A similar initial increase in ABA content was observed in EMs matured on 4G, but after 4 weeks of maturation, the ABA content was less than half $\left(9.0 \mathrm{nmol} \mathrm{g}^{-1} \mathrm{DW}\right)$ that on $9 \mathrm{G}$.

\section{Carbohydrate and total protein contents}

17 At 1 week of maturation, similar amounts of total protein were observed for EMs developed on $4 \mathrm{G}$ or 9G (Table 1). In contrast, significant differences in carbohydrates contents were observed. EMs matured on 4G had a greater amount of fructose (Fru, $27.4 \mu \mathrm{g} \mathrm{g}^{-1} \mathrm{DW}$ ) and glucose (Glu, $26.6 \mu \mathrm{g} \mathrm{g}^{-1}$ DW) but a similar sucrose content ( $\mathrm{Su}, 6.88 \mu \mathrm{g} \mathrm{g}^{-1} \mathrm{DW}$ ) to that of EMs matured on 9G. In consequence, the ratio $(\mathrm{Fru}+\mathrm{Glu}) / \mathrm{Su}$ was significantly higher for EMs matured on $4 \mathrm{G}$ than for those matured on 9G (7.9 and 4.4, respectively). Other carbohydrates such as stachyose, raffinose, maltose and mannose were not detected whatever the conditions. Finally, EMs matured on 9G contained a significantly larger amount of starch $\left(46.30 \mu \mathrm{g} \mathrm{g}^{-1} \mathrm{DW}\right)$ than those matured on $4 \mathrm{G}\left(32.70 \mu \mathrm{g} \mathrm{g}^{-1} \mathrm{DW}\right)$.

\section{Transcriptomic analysis}

1103 transcripts were considered to be differentially expressed, 632 for EMs matured on 9G and 471 for EMs matured on 4G (Appendix S1 in Supporting Information).

Data annotation by enrichment analysis and functional classification. Using the Blast2GO program, significant transcripts were annotated against the Plants/Arabidopsis thaliana section of the protein sequences database. Next, the annotated significant transcripts were mapped against the GO database to retrieve the relevant GO terms. In total $4865 \mathrm{GO}$ terms were assigned to the 529 mapped transcripts with an average of five GO terms assigned to each transcript. Of these GO terms, the majority were assigned to the Biological Process category (3118, 64\%), followed by Molecular Function (1217, 25\%), and Cellular Component (530, 11\%).

36 GO analysis at level 2, illustrating the Biological Process categories, is presented in the "Hit 37 description" column of Appendix S2 in Supporting Information. Within the Biological Process 
Version définitive du manuscrit publié dans / Final version of the manuscript published in : Physiologia Plantarum, 2014, 152(1), 184-201 http://dx.doi.org/10.1111/ppl.12158

1 ontology, proteins involved in cellular process, metabolic process and response to stimulus 2 predominated.

3 Figure 5 shows the results of GO enrichment analysis, illustrating the distribution of Biological 4 Process GO terms that were differentially enriched for EMs matured on $4 \mathrm{G}$ versus 9G. Twenty-one 5 functional categories were represented by 298 sequences originating from EMs matured on $4 \mathrm{G}$ and 6239 sequences from 9G. The majority of the significant categories for EMs matured on 4G were 7 involved in carbohydrate metabolism, energy metabolism and cellular respiration, while for EMs 8 matured on $9 \mathrm{G}$ the significant categories were cell growth and embryo-related development, regulation 9 response to stimulus and secondary metabolic processes.

10 In order to identify the biological pathways active in early EM maturation, the assembled ESTs were 11 used to obtain the corresponding Enzyme Commission numbers (ECs) by annotation against the 12 KEGG database. A total of 207 transcripts were assigned to 40 ECs. The ECs were then grouped into 1356 biochemical pathways, of which 33 pathways were found to be involved in metabolism. Most 14 enzymes active in EMs matured on $4 \mathrm{G}$ participate in the glycolysis/gluconeogenesis pathway (23) and 15 16

Transcript expression levels.

18 Among the 471 transcripts overexpressed in EMs grown on 4G, the most prominent were 9 encoding 19 "pyruvate decarboxylase" with a mean of 12.0 FPKM, 7 encoding "alcohol dehydrogenase" (8.3 20 FPKM), 7 annotated as "bifunctional enolase 2" and related to a glucose catabolic process (15.2 21 FPKM), 1 annotated as "6-phosphofructokinase 2" involved in glycolysis (7.5 FPKM) and 1 annotated 22 as "sucrose synthase 3" responsive to oxygen levels (9.8 FPKM).

23 For EMs grown on 9G, the most interesting transcripts among the 632 that were overexpressed are 20 24 annotated as either "SUMO-conjugating enzyme" or "ubiquitin-conjugating enzyme" (25.6 FPKM) 25 with an ontology related to endosperm development, 5 encoding "Naringenin,2-oxoglutarate 326 dioxygenase", also known as flavanone 3-hydroxylase $(\mathrm{F} 3 \mathrm{H})$ and associated with a flavonoid 27 biosynthetic process (8.1 FPKM), 3 encoding "chitinase" (18.6 FPKM), 2 transcript for "protein 28 phosphatase $2 \mathrm{C} 16$ " which is putatively involved in negative regulation of the abscisic acid mediated 29 signaling pathway (28.3 FPKM), and 3 "serine/threonine-protein kinases" transcripts reported as being 30 involved in the positive regulation of abscisic acid-mediated signaling pathway, SRK2E (55.2 FPKM) and SRK2H (18.3 FPKM). In addition, one transcript annotated as "pollen Ole e 1 allergen and extensin family protein", but with a weak similarity of $47 \%$, was the most highly over-expressed transcript, at 230.4 FPKM.

\section{2-D gel proteomic analysis}

36 Changes in EM protein profiles were investigated using 2D gel electrophoresis. Separation with high 37 resolution was achieved, allowing detection of a total of 1,428 spots (representative gel shown in 
1 Appendix S3 in the Supporting Information). The gellan gum concentration had no significant effect

2 (t-test, $P<0.05$ ), on the normalized volumes of most spots. Significant differences were detected for

3 only 83 spots, 35 with greater abundance on $4 \mathrm{G}$ and 48 on $9 \mathrm{G}$. Of the significant spots, 58 were picked

4 for analysis by mass spectrometry. Protein identification was successful for 56 spots, 27 of which were

5 overproduced on $4 \mathrm{G}$ and 29 on $9 \mathrm{G}$ (Table 2). Detailed information on the statistical parameters used

6 for protein identification is given in Appendix S4 in the Supporting Information. All identified

7 proteins were grouped into functional categories within the Biological Process ontology (level 2) using

8 Blast2GO (Appendix S5 in Supporting Information). A striking result of this classification was that

9 around $50 \%$ of all spots identified were placed in only three categories: metabolic process, cellular

10 process and response to stimulus.

\section{Discussion}

13 We determined key molecular, physiological and biological parameters in order to develop a 14 comprehensive picture of SE maturation in maritime pine. In addition to SE growth and water content, 15 we measured endogenous ABA, total protein, soluble carbohydrate and starch contents. We also 16 tentatively identified as many protein and transcript levels as possible in order to gain information 17 about the cellular environment as a whole. For this study, we used a culture medium parameter 18 specifically appropriate for pine species, namely gellan gum concentration, to trigger the maturation 19 process. Transcriptomic and proteomic analyses were performed at week 1 after initiation of cultures, 20 whereas other parameters were monitored weekly. This sampling strategy was designed to focus 21 mainly on early molecular mechanisms (as reflected in transcript and protein profiles) that could be 22 involved in subsequent physiological modifications promoting SE development.

23 Since the Pinus pinaster genome has yet not been completely sequenced, we are aware that it is not 24 currently possible to infer numbers of genes per gene family. 'Hence, we cannot estimate whether variant transcripts detected in this study represent alternative transcripts from individual members of gene families or are products of paralogs. 'However, we can state with confidence that each short-read pair that we obtained mapped specifically to one reference transcript, and the results indicate some diversity in the range of transcripts deriving from different gene families; further characterization of these families at the genome level is still necessary. We decided to limit data analysis to the genes that were most differentially expressed according to FPKM ratio statistics. These genes were grouped on the basis of GO annotation at the Biological Process level. From this data analysis, it appears that EMs expressed markedly different set of genes according to the maturation medium used.

\section{Does gellan gum concentration control maturation of somatic embryos?}

35 When compared to the lower concentration, $4 \mathrm{G}$, it appears that on $9 \mathrm{G}$, maritime pine SE differentiated 36 better, based on macroscopical and histological observations (Fig. 1, 2), and on measurements of DW 37 and water content (Fig. 3). Our results reinforce findings previously reported for somatic 
Version définitive du manuscrit publié dans / Final version of the manuscript published in : Physiologia Plantarum, 2014, 152(1), 184-201 http://dx.doi.org/10.1111/ppl.12158

1 embryogenesis in white pine (Klimaszewska et al. 2000), and Scots pine (Lelu-Walter et al. 2008), 2 where high gellan gum concentrations were linked to lower water availability and enhanced SE

3 development. Low water and carbon source availability also had a major impact on SE maturation and 4 germination in carrot (Lee et al. 2001), suggesting that the induction of embryo development by 5 temporary growth starvation observed in natural conditions can be mimicked in vitro in a broad range 6 of species. Our results indicate that gellan gum concentration and associated modulation of water 7 availability in the medium is critical in controlling SE development in maritime pine.

9 What happens in EMs when somatic embryo maturation is hindered?

Microscopic observations (Fig. 1) showed that EMs grown on $4 \mathrm{G}$ produced less structured immature embryos and more undifferentiated tissues through cell proliferation (Fig. 2), an observation corroborated by the increase in FW due mainly to water uptake throughout the culture period (Fig. 3). In general, for pine species maturation in the presence of low concentrations of gelling agent sustains proliferation of immature SE but is detrimental to SE development (Klimaszewska et al. 2000). In 4G-grown EMs, endogenous synthesis of $\mathrm{ABA}$ is limited and there is no detectable $\mathrm{ABA}$ conjugation, at least via ABAGE synthesis. We avoided exogenous application of $\mathrm{ABA}$ at levels high enough to obscure endogenous ABA synthesis by several orders of magnitude because of the occurrence of high levels of ABA conjugation (Daie et al. 1984) as reported for larch (Label and Lelu, 2000).

20 Carbohydrate contents in EMs cultured on $4 \mathrm{G}$ is characterized by a high hexose:sucrose ratio, and fairly low starch accumulation which is in accordance with microscopic observations (Fig. 1e). These results suggest stimulation of the glycolytic pathway, possibly related to cell proliferation (Fig.2a). A high hexose:sucrose ratio has been observed in proliferating conifer EMs (Lipavská and Konrádová, 2004).

Transcriptionally, our results show an increased level of expression of alcohol dehydrogenase (ADH) and pyruvate decarboxylase (PDC) genes in 4G-grown EMs, along with over-expression of sucrose synthase. At the proteomic level, ADH, phosphoglycerate kinase and PDC isozyme 2 are also significantly up-regulated. The two datasets are consistent, and support possible stimulation of the glycolytic pathway, as also suggested by the results of carbohydrate analysis. However a recent paper on Arabidopsis reported that ADH and PDC enzymes and their corresponding transcripts could be modulated to overcome unfavorable conditions such as anoxia brought about by submergence in culture medium (Mithran et al. 2013). In addition, utilization of sucrose, provided in our study by the culture medium, is important in anoxia tolerance mediated by alcoholic fermentation (Loreti et al. 2005). These findings, taken together with our results, suggest that for EMs, $4 \mathrm{G}$ is i) a condition unfavorable for SE differentiation and maturation, possibly due to an excess of water at this low gellan 
Version définitive du manuscrit publié dans / Final version of the manuscript published in : Physiologia Plantarum, 2014, 152(1), 184-201 http://dx.doi.org/10.1111/ppl.12158

1 glycolysis pathway genes) that could result in the rapid onset (within 1 week) of alcoholic

2 fermentation (expression of anoxia-related genes) and cell senescence.

3 Additionally, in EMs grown on $4 \mathrm{G}$ we observed over-expression of several bifunctional enolase-2

4 transcripts which may be related to abiotic stress-regulated transcriptional networks (Chinnusamy et

5 al. 2007). Bifunctional enolase 2, also known as low expression of osmotically responsive genes 2

6 (LOS2), appears to be a negative regulator of transcription factors involved in abiotic stress responses.

7 This result again suggests that $4 \mathrm{G}$ may be a stressful culture condition for both cell proliferation and

8 (to an even greater extent) differentiation.

9 Our proteomic results revealed a high level of protein synthesis after 1 week of maturation on 4G. This

10 is probably a prerequisite for cell division. We identified many transcripts (cell division control

11 protein 48 -e, growth-regulating factor 5 and mitogen-activated protein kinase 6) and proteins (DNA

12 replication licensing factor MCM3 homolog 3 and cell division protein FtsQ) involved in both DNA

13 replication and cell division on 4G. Because of the increase in FW and DW and the histological results

14 (Fig. 1), we propose that these genes and their products may be involved in cell proliferation. One of

15 the most significantly overexpressed proteins on $4 \mathrm{G}$ is related to a $26 \mathrm{~S}$ proteasome regulatory subunit

16 which is involved in selective breakdown of proteins (Vierstra, 2003) but also in many other aspects of

17 cell regulation including embryogenesis and cell senescence. This is an interesting point, since we 18 observed necrotic cells in meristematic centers as early as 2-3 weeks after the start of maturation (Fig.

19 1). High $26 \mathrm{~S}$ proteasome subunit activity suggests both active regulation of cell proliferation and 20 senescence on $4 \mathrm{G}$. No related transcripts could be detected in the same samples, but transcript 21 abundance is not always well correlated with levels of the final products (Dembinsky et al. 2007; Pan 22 et al. 2012).

\section{Which components appear during maturation of somatic embryos?}

25 ABA is synthesized at a low level during the three first weeks of culture (Fig. 4), but peaks at week 4 when SE are differentiating, while the water content remains relatively high. On 9G the EMs are not much dehydrated, even though water availability is relatively limited compared to that on $4 \mathrm{G}$. The major increase in $\mathrm{ABA}$ at week 4 suggests that there is an ontogenetic signal for SE development at this stage, as has been observed in larch (Label and Lelu, 2000). For instance, many ubiquitin-protein ligase transcripts are detected in 9G. More recent findings indicate that this enzyme is associated with the activation of the small ubiquitin-related modifier (SUMO), leading to specific post-transcriptional modifications of chromatin and thereby influencing gene transcription (Cubenas-Potts and Matunis, 2013). Our results suggest that in differentiated EMs, gene expression at week 1 may be undergoing large-scale reorganization to promote SE development. In addition to the ubiquitin-protein ligase transcripts, two proteasome subunit beta type-1 proteins were identified among the proteins overexpressed on 9G. The ubiquitin/proteasome pathway is reported to be a major factor in controlled 
1 complex. This pathway supplies amino acids for the biosynthesis of new proteins (Vierstra, 2003). A

2 recent paper (Rode et al. 2012) links high levels of enzymes involved in the proteasome-dependent

3 proteolysis pathway and the switch from callus to globular embryos in cyclamen.

4 During somatic embryogenesis in gymnosperms, chitinases are reportedly excreted into the culture 5 medium. These enzymes are involved in the regulation of the EM-to-SE transition and massive 6 programmed cell death (Wiweger et al. 2003; Vestman et al. 2011). Our results showed over7 expression of transcripts for chitinase in EMs grown on 9G. In Norway spruce, programmed cell death 8 is responsible for the degradation of EMs when early SEs differentiate (Vestman et al. 2011). The 9 timing of programmed cell death can also be modulated by disulfide isomerase, which was upregulated on 9G. This enzyme seems to be required for proper embryo development in Arabidopsis seeds (Andème-Ondzighi et al. 2008). Expansin S2 and putative expansin-B14 are known to play roles in embryogenesis. In Arabidopsis, they are involved in the cell cycle, as key regulators of wall and cell expansion (Thibaud-Nissen et al. 2003; Spencer et al. 2007). The proteins tubulin beta-2 chain and GTP-binding nuclear protein Ran-A1 participate in cytoskeletal process such as nucleocytoplasmic transport (Pan et al. 2009; Vernoud et al. 2003). All these proteins, which are up-regulated in 9G, may direct cell division towards cell remodeling for embryogenesis, a hypothesis consistent with our 17 histological observations.

Several serine/threonine kinase (SRK2) transcripts are highly over-expressed in EMs growing on. SRK2s are plant homologs of AMPK/SNF1 genes, which in other eukaryotes are considered to be crucial in linking stress and metabolic responses (Kulik et al. 2011). They are reported to be key players in osmotic stress responses and ABA-dependent plant development (Fujii et al. 2011). Endogenous ABA synthesis was significantly enhanced on 9G, i.e when water availability was reduced. In addition, the detection of highly over-expressed protein phosphatase $2 \mathrm{C}$ (PP2C) transcripts in $9 \mathrm{G}$ grown EMs reinforces the likelihood of such a - possibly adaptive - molecular response (Sheen, 1998). PP2Cs are reported to be key protein-protein interactors mediating ABA responses in plants (Yoshida et al. 2006). Our results suggest that immature SE respond to reduced availability of water in the maturation medium through ABA-mediated molecular mechanism.

Two superoxide dismutases are overexpressed at the proteomic level, as is one germin-like protein. This latter is also detected at the transcriptomic level, suggesting an ongoing process of antioxidant protein production through mRNA synthesis EMs growing on 9G. The role of germin-like proteins in plant development and defense is well documented (Bernier and Berna, 2001). Their involvement as markers of early stages of somatic embryogenesis in both conifers (Neutelings et al. 1998; Mathieu et al. 2006) and angiosperms (Caliskan et al. 2004; Kim and Triplett, 2004) makes them especially valuable in this context. Superoxide dismutase is involved in the regulation of oxidative stress. It destroys free radicals which are normally produced within the cells and are toxic to biological systems. In a proteomic study on the early stages of seed development in Pinus massoniana, a correlation was established between the level of this protein and the transition from the pro-embryo to the columnar 
Version définitive du manuscrit publié dans / Final version of the manuscript published in : Physiologia Plantarum, 2014, 152(1), 184-201 http://dx.doi.org/10.1111/ppl.12158

1 embryo stage (Zhen et al. 2012). It has been suggested that the ability of embryos to develop an

2 efficient redox homeostasis system may be key for successful regulation and maintenance of cell 3 differentiation.

4 Our results also show that many transcripts related to $\mathrm{F} 3 \mathrm{H}$, as well as several other transcripts related 5 to flavonol metabolism, are over-expressed in 9G-grown EMs. F3H catalyses hydroxylation of 6 flavanones to dihydroflavonols. Flavonoids are ubiquitous in plants, and some of these compounds 7 play specific roles in seed development (Lepiniec et al. 2006). Among these roles, stress resistance is a 8 key biological function which leads to the synthesis of several secondary compounds all related to 9 flavanones hydroxylation and subsequent metabolism down to condensed tannins (Winkel-Shirley, 2002). Our results suggest that EMs cultivated on $9 \mathrm{G}$ may overcome constraints imposed by culture conditions by synthesizing protective secondary metabolites. This does not seem to occur in EMs grown on $4 \mathrm{G}$, where many stress response-related transcripts were identified as discussed above. At the proteomic level, two enzymes (glucose-1-phosphate adenylyltransferase AGPP; 4-alphaglucanotransferase DPE2, disproportionating enzyme) reportedly involved in starch biosynthesis (Keeling and Myers, 2010) were found to be overexpressed on 9G. This is consistent with the high starch content of immature SE cultivated in these favorable conditions (Fig. 1, Table 1). It is interesting to note that glucose and fructose contents were correlated with the difference in starch grain accumulation on 4G and 9G (Fig. 1e, f; Table 1). In maritime pine, a low abundance of starch granules was reported in proliferating EMs (Breton et al. 2005) whereas starch was found to accumulate throughout developing embryos during early maturation (Tereso et al. 2007). A similar picture was reported during larch SE maturation (Gutmann et al. 1998).

\section{Conclusions}

24 This is the first study on the early molecular mechanisms involved in somatic embryogenesis of pine following an increase in gellan gum concentration in the medium, and it is also the first report combining transcriptomic and proteomic data on somatic embryogenesis in conifers. Our transcriptomic and proteomic results indicate that glycolysis is enhanced under conditions unfavourable for SE maturation (4G) which lead to EM proliferation. Under favourable conditions (9G), we observed adaptive, ABA-mediated molecular and physiological responses to reduced water availability resulting in early transition of EMs from proliferation to the SE developmental pathway (indicated by active protein synthesis, and overexpression of proteins involved in cell division, embryogenesis and starch synthesis). Specific pathways (synthesis of protective secondary metabolites, regulation of oxidative stress) are concomitantly activated, apparently to overcome constraints due to culture conditions.

35 Based on both our transcriptomic and proteomic data and related information available in the 36 literature, we proposed the germin-like protein and ubiquitin-protein ligase as potential marker genes 37 and proteins for early evidence of effective SE development on maturation medium. Protein- 
Version définitive du manuscrit publié dans / Final version of the manuscript published in : Physiologia Plantarum, 2014, 152(1), 184-201 http://dx.doi.org/10.1111/ppl.12158

1 phosphatase 2C (PP2C) may be also a suitable marker for monitoring adaptive molecular responses to 2 favourable maturing conditions that may have a beneficial impact on regeneration capacity of cultures.

3 The identification of relevant biomarkers at the molecular level needs validation experiments but has 4 clear practical implications for implementation of somatic embryogenesis in both conifer fundamental 5 research and commercial applications. Functional genomics based on reverse genetics in maritime pine 6 is a long process requiring transgenic plant regeneration through somatic embryogenesis and 7 cryopreservation of selected transgenic lines (Trontin et al. 2002). Labor intensiveness would be 8

\section{Author contributions}

AM participated in the acquisition of the data, carried out all types of analyses and drafted the manuscript. CT conceived in the design of the study, participated in 2-D gel proteomic analysis and drafted the manuscript. JFT conceived in the design of the study, participated in somatic embryogenesis and drafted the manuscript. KE carried out histological and microscopical analysis and drafted the manuscript. BP carried out $\mathrm{ABA}$ and $\mathrm{ABA}$ GE analyses. MB carried out Gel spot processing and protein identification by database sequence assignment. DM participated in the design of the study and helped to draft the manuscript. NB carried out carbohydrate analyses and helped to draft the manuscript. CLM carried out somatic embryogenesis and collected the material. LB-B participated in 2-D gel proteomic analyses. IR carried out somatic embryogenesis and collected the material. LH participated in the design of the study and helped to draft the manuscript. MC participated in gel spot processing and protein identification by database sequence assignment and helped to draft the manuscript. FC participated in study design, participated in carbohydrate analysis and drafted the manuscript. MV participated in the design of the study and drafted the manuscript. PL conceived in the design of the study, carried out transcriptomic analysis, performed the statistical analysis and drafted the manuscript. MALW conceived in the design of the study and its coordination, and drafted the manuscript. All authors read and approved the final manuscript.

\section{Acknowledgments}

36 This work was supported by grants from the French "Conseil Régional de la Région Centre" 37 (EMBRYOME project, contract 33639), the "Conseil Régional de la Région Aquitaine" (Embryo2011, 
Version définitive du manuscrit publié dans / Final version of the manuscript published in :

Physiologia Plantarum, 2014, 152(1), 184-201 http://dx.doi.org/10.1111/ppl.12158

1 contract 09012579-045), and the French Ministry of Foreign Affairs and the French Ministry of

2 Higher Education and Research through the France/Czech Republic Science Cooperation

3 BARRANDE Programme. Data analysis was made possible through the involvement of INRA's

4 GenoToul bioinformatics platform in Toulouse (France).

5 
Version définitive du manuscrit publié dans / Final version of the manuscript published in : Physiologia Plantarum, 2014, 152(1), 184-201 http://dx.doi.org/10.1111/ppl.12158

\section{Bibliography}

2 Andème-Ondzighi C, Christopher DA, Cho EJ, Chang S-C, Staehelin LA (2008) Arabidopsis protein

3 disulfide isomerase-5 inhibits cysteine proteases during trafficking to vacuoles before programmed

4 cell death of the endothelium in developing seeds. Plant Cell 20: 2205-2220

5 Attree SM, Fowke LC (1993) Embryogeny of gymnosperms: advances in synthetic seed technology of 6 conifers. Plant Cell Tiss Org 35: 1-35

7 Beaufour M, Godin F, Vallée B, Cadene M, Bénédetti H (2012) Interaction proteomics suggests a new 8 role for the Tfs1 protein in yeast. J Proteome Res 11: 3211-3218

Benjamini Y, Hochberg Y (1995) Controlling the False Discovery Rate: a practical and powerful approach to multiple testing. J Royal Stat Society, Series B 57: 289-300

Bernier F, Berna A (2001) Germins and germin-like proteins: Plant do-all proteins. But what do they do exactly? Plant Physiol Bioch 39: 545-554

13 Bergmeyer HU, Bernt E, Schmidt F, Stork H (1974) D-glucose. In: Bergmeyer HU (ed) Methods of enzymatic analysis, vol III. Verlag Chemie, Weinheim, pp 1196-1201

Black M (1991) Involvement of ABA in the physiology of developing and mature seeds. In: Davies WJ, jones HG (eds) Abscisic acid: physiology and biochemistry. Oxford: BIOS Scientific Publisher pp 99-124

Black M, Corbineau F, Grzesik M, Guy P, Côme D (1996) Carbohydrate metabolism in the developing and maturing wheat embryo in relation to its desiccation tolerance. J Exp Bot 47: 161169

Breton D, Harvengt L, Trontin J-F, Bouvet A, Favre J-M (2005) High subculture frequency, maltosebased and hormone-free medium sustained early development of somatic embryos in maritime pine. In Vitro Cell Dev Biol Plant 41: 494-504

Caliskan M, Turet M, Cuming A (2004) Formation of wheat (Triticum aestivum L.) embryogenic callus involves peroxide-generating germin-like oxalate oxidase. Planta 219: 132-140

Cairney J, Pullman GS (2007) The cellular and molecular biology of conifer embryogenesis. New Phytologist 176: 511-536

Chinnusamy V, Zhu J, Zhu J-K (2007) Cold stress regulation of gene expression in plants. Trends Plant Sci 12: 444-451

30 Conesa A, Gotz S, Garcia-Gomez JM, Terol J, Talon M, Robles M (2005) Blast2GO: a universal tool 31 for annotation, visualization and analysis in functional genomics research. Bioinformatics, 21: 367432 3676

33 Cubenas-Potts C, Matunis MJ (2013) SUMO: A multifaceted modifier of chromatin structure and 34 function. Developmental Cell 24: 1-12

35 Daie J, Wyse R, Hein M, Brenner ML (1984) Abscisic acid metabolism by source and sink tissues of 36 sugar beet. Plant Physiol74: 810-814 
Version définitive du manuscrit publié dans / Final version of the manuscript published in :

Physiologia Plantarum, 2014, 152(1), 184-201 $\quad$ http://dx.doi.org/10.1111/ppl.12158

1 Dembinsky D, Woll K, SaleemM, LiuY, Fu Y, Borsuk LA, Lamkemeyer T, Fladerer C, Madlung J,

2 Barbazuk B, Nordheim A, Nettleton D, Schnable PS, Hochholdinger F (2007) Transcriptomic and

3 proteomic analyses of pericycle cells of the maize primary root. Plant Physiol 145: 575-588

4 Dogra PD (1978) Morphology, development and nomenclature of conifer embryo. Phytomorphology

$5 \quad 28: 307-322$

6 Dronne S, Label P, Lelu M-A (1997) Desiccation decreases abscisic acid content in hybrid larch

7 (Larix $\times$ leptoeuropaea) somatic embryos. Physiol Plant 99: 433-438

Fujii H, Verslues PE, Zhu J-K (2011) Arabidopsis decuple mutant reveals the importance of SnRK2

kinases in osmotic stress responses in vivo. Proceedings National Acad Sci 108: 1717-1722

Gutmann M, Von Aderkas P, Label P, Lelu M-A (1996) Effects of abscisic acid on somatic embryo maturation of hybrid larch. J Exp Bot 47: 1905-1917

Harfouche A, Meilan R, Kirst M, Morgante M, Boerjan W, Sabatti M, Scarascia Mugnozza G (2012)

Accelerating the domestication of forest trees in a changing world. Trends Plant Sci 17: 64-72

Jennissen H (1995) Ubiquitin and the Enigma of Intracellular Protein Degradation. European J Bioch

231: $1-30$

Jones KH, Senft JA (1985) An improved method to determine cell viability by simultaneous staining with fluorescein diacetate-propidium iodide. J Histoch Cytoch 33: 77-79

Kapik RH, Dinus RJ, Dean, JFD (1995) Abscisic acid and zygotic embryogenesis in Pinus taeda. Tree Physiol 15: 485-490

Keeling PL, Myers AM (2010) Biochemistry and genetics of starch synthesis. Annual Review Food Sci Technol 1:271-303

Kim H, Triplett B (2004) Cotton fiber germin-like protein. I. Molecular cloning and gene expression.

Planta 218: 516-524

King RW (1982) Abscisic acid in seed development. In: Khan AA (ed) Physiology and biochemistry of seed development, dormancy and germination, Elsevier Biomedical press, Amsterdam, pp 157181

Klimaszewska K, Smith D (1997) Maturation of somatic embryos of Pinus strobus is promoted by a high concentration of gellan gum. Physiol Plant 100: 949-957

Klimaszewska K, Bernier-Cardou M, Cyr DR, Sutton BCS (2000) Influence of gelling agents on culture medium gel strength, water availability, tissue water potential, and maturation response in embryogenic cultures of Pinus strobus L. In Vitro Cell Dev Biol Plant 36: 279-286

Kong L, Attree SM, Fowke LC (1997) Changes of endogenous hormone levels in developing seeds, zygotic embryos and megagametophytes in Picea glauca. Physiol Plant. 101: 23-30

Kulik A, Wawer I, Krzywinska E, Bucholc M, Dobrowolska G (2011) SnRK2 protein kinases-key regulators of plant response to abiotic stresses. Omics: a journal of integrative biology 15: 859-872 
Version définitive du manuscrit publié dans / Final version of the manuscript published in :

Physiologia Plantarum, 2014, 152(1), 184-201 http://dx.doi.org/10.1111/ppl.12158

1 Lara-Chavez A, Egertsdotter U, Flinn BS (2012) Comparison of gene expression markers during

2 zygotic and somatic embryogenesis in pine. In Vitro Cell Dev Biol Plant 48: 341-354

3 Lee EK, Cho DY, Soh WY (2001) Enhanced production and germination of somatic embryos by temporary starvation in tissue cultures of Daucus carota. Plant Cell Rep 20: 408-415

5 Lepiniec L, Debeaujon I, Routaboul J-M, Baudry A, Pourcel L, Nesi N, Caboche M (2006) Genetics

6 and biochemistry of seed flavonoids. Annual Review Plant Biol 57: 405-430

Lelu-Walter M-A, Bernier-Cardou M, Klimaszewska K (2006) Simplified and improved somatic embryogenesis for clonal propagation of Pinus pinaster Ait. Plant Cell Rep 25: 767-776

Lelu-Walter M-A, Bernier-Cardou M, Klimaszewska K (2008) Clonal plant production from self- and cross-pollinated seed families of Pinus sylvestris (L.) through somatic embryogenesis. Plant Cell Tiss Org Cult 92: 31-45

Lelu-Walter M-A, Thompson D, Harvengt L, Sanchez L, Toribio M, Pâques LE (2013) Somatic embryogenesis in forestry with a focus on Europe: state-of-the-art, benefits, challenges and future direction. Tree Genet Gen 9: 883-899

Li H, Durbin R (2009) Fast and accurate short read alignment with Burrows-Wheeler transform. Bioinformatics 25: 1754-1760

Lipavská H, Konrádová (2004) Somatic embryogenesis in conifers: the role of carbohydrate metabolism. In Vitro Cellular and Developmental Biology - Plant 40: 23-30

Lipavská H, Svobodová H, Albrechtová J, Kumstýřová L, Vágner M, Vondráková Z (2000) Somatic embryogenesis in Norway spruce: carbohydrate status during embryo maturation and the effect of polyethylene glycol treatment. In Vitro Cell Dev Biol Plant 36: 260-267

Lippert D, Jun Z, Ralph S, Ellis DE, Gilbert M, Olafson R, Ritland K, Ellis B, Douglas CJ, Bohlmann J (2005) Proteome analysis of early somatic embryogenesis in Picea glauca. PROTEOMICS 5: 461473

Litvay JD, Verma DC, Johnson MA (1985) Influence of loblolly pine (Pinus taeda L.) culture medium and its components on growth and somatic embryogenesis of the wild carrot (Daucus carota L.). Plant Cell Rep 4: 325-328

Loreti E, Poggi A, Novi G, Alpi A, Perata P (2005) A genome-wide analysis of the effects of sucrose on gene expression in Arabidopsis seedlings under anoxia. Plant Physiol 137: 1130-1138 genes are expressed during somatic embryogenesis and early development of conifers. Plant Mol Biol 61: 615-627

33 Mithran M, Paparelli E, Novi G, Perata P, Loreti E (2013) Analysis of the role of the pyruvate 34 decarboxylase gene family in Arabidopsis thaliana under low-oxygen conditions. Plant Biology, (in 35 press) doi: 10.1111/plb.12005 
Version définitive du manuscrit publié dans / Final version of the manuscript published in :

Physiologia Plantarum, 2014, 152(1), 184-201 $\quad$ http://dx.doi.org/10.1111/ppl.12158

1 Neutelings G, Domon JM, Membre N, Bernier F, Meyer Y, David A, David H (1998) Characterization

2 of a germin-like protein gene expressed in somatic and zygotic embryos of pine (Pinus caribaea

3 Morelet). Plant Mol Biol 38: 1179-1190

4 Ogata H, Goto S, Sato K, Fujibuchi W, Bono H, Kanehisa M (1999) KEGG: Kyoto Encyclopedia of

5 Genes and Genomes. Nucleic Acids Research 27: 29-34

6 Pan Z, Guan R, Zhu S, Deng X (2009) Proteomic analysis of somatic embryogenesis in Valencia 7 sweet orange (Citrus sinensis Osbeck). Plant Cell Rep 28: 281-289

8 Pan Z, Zeng Y, An J, Ye JXu Q, Deng X (2012) An integrative analysis of transcriptome and

9 proteome provides new insights into carotenoid biosynthesis and regulation in sweet orange fruits. $\mathrm{J}$

10 Proteomics 75: 2670-2684

11 Park YS (2002) Implementation of conifer somatic embryogenesis in clonal forestry: technical 12 requirements and deployment considerations. Annals For Sci 59: 651-656

13 Park YS, Lelu-Walter M-A, Harvengt L, Trontin JF, McEacheron I, Klimaszewska K, Bonga JM 14 (2006) Initiation of somatic embryogenesis in Pinus banksiana, P. strobus, P. pinaster, and $P$. 15 sylvestris at three laboratories in Canada and France. Plant Cell Tiss Org Cult 86: 87-101

Pérez Rodríguez MJ, Suárez MF, Heredia R, Ávila C, Breton D, Trontin J-F, Filonova L, Bozhkov P,

17 Von Arnold S, Harvengt L, Cánovas FM (2006) Expression patterns of two glutamine synthetase 18 genes in zygotic and somatic pine embryos support specific roles in nitrogen metabolism during 19 embryogenesis. New Phytologist 169: 35-44

20 Petřek J, Víteček J, Vlašínová H, Kizek R, Kramer KJ, Adam V, Klejdus B, Havel L (2005) 21 Application of computer imaging, stripping voltammetry and mass spectrometry to study the effect of lead (Pb-EDTA) on the growth and viability of early somatic embryos of Norway spruce (Picea abies L. Karst.). Analytical Bioanalytical Chemistry 383: 576-586

R Development Core Team (2011) R: A language and environment for statistical computing. R Foundation for Statistical Computing, Vienna, Austria. ISBN 3-900051-07-0, URL http://www.Rproject.org/

Ramarosandratana A, Harvengt L, Bouvet A, Calvayrac R, Pâques M (2001) Effects of carbohydrate source, polyethylene glycol and gellan gum concentration on embryonal-suspensor mass (ESM) proliferation and maturation of maritime pine somatic embryos. In Vitro Cell Dev Biol Plant 37: 2934

Roberts A, Trapnell C, Donaghey J, Rinn J, Pachter L (2011) Improving RNA-Seq expression estimates by correcting for fragment bias. Genome Biol 12: R22

Rode C, Lindhorst K, Braun H-P, Winkelmann T (2012) From callus to embryo: a proteomic view on the development and maturation of somatic embryos in Cyclamen persicum. Planta 235: 995-1011

Sallandrouze A, Faurobert M, El Maataoui M, Espagnac H (1999) Two-dimensional electrophoretic analysis of proteins associated with somatic embryogenesis development in Cupressus sempervirens L. Electrophoresis 20: 1109-1119 
Version définitive du manuscrit publié dans / Final version of the manuscript published in : Physiologia Plantarum, 2014, 152(1), 184-201 http://dx.doi.org/10.1111/ppl.12158

1 Sheen J (1998) Mutational analysis of protein phosphatase 2C involved in abscisic acid signal 2 transduction in higher $\square$ plants. Proceedings National Acad Sci 95: 975-980

3 Stasolla C, Kong L, Yeung EC, Thorpe T (2002) Maturation of somatic embryos in conifers: 4 morphogenesis, physiology, biochemistry, and molecular biology. In Vitro Cell Dev Biol Plant 38: $5 \quad 93-105$

6 Stasolla C, Bozhkov PV, Chu T-M, Van Zyl L, Egertsdotter U, Suarez MF, Craig D, Wolfinger RD, 7 Von Arnold S, Sederoff RR (2004) Variation in transcript abundance during somatic embryogenesis 8 in gymnosperms. Tree Physiol 24: 1073-1085

Spencer MWB, Casson SA, Lindsey K (2007) Transcriptional profiling of the arabidopsis embryo. Plant Physiol 143: 924-940

Tereso S, Zoglauer K, Milhinhos A, Miguel C, Oliveira M (2007) Zygotic and somatic embryo morphogenesis in Pinus pinaster: comparative histological and histochemical study. Tree Physiol 27: 661-669

Teyssier C, Grondin C, Bonhomme L, Lomenech A-M, Vallance M, Morabito D, Label P, LeluWalter M-A (2011) Increased gelling agent concentration promotes somatic embryo maturation in hybrid larch (Larix x eurolepis): a 2-DE proteomic analysis. Physiol Plant 141: 152-165

Teyssier C, Maury S, Beaufour M, Grondin C, Delaunay A, Le Metté C, Ader K, Cadene M, Label P, Lelu-Walter M-A (2013) In search of markers for somatic embryo maturation in hybrid larch (Larix $\mathrm{x}$ eurolepis): global DNA methylation and proteomic analyses. Physiol Plant (in press) doi: 10.1111/ppl.12081

Thibaud-Nissen F, Shealy RT, Khanna A, Vodkin LO (2003) Clustering of microarray data reveals transcript patterns associated with somatic embryogenesis in soybean. Plant Physiol 132: 118-136

Trontin J-F, Harvengt L, Garin E, Vernaza ML, Arancio L, Hoebeke J, Canlet F, Paques M (2002) Towards genetic engineering of maritime pine (Pinus pinaster Ait.). Annals of Forest Science 59: $687-697$

Umezawa T, Sugiyama N, Mizoguchi M, Hayashi S, Myouga F, Yamaguchi-Shinozaki K, Ishihama activated protein kinases in Arabidopsis. Proceedings National Acad Sci 106: 17588-17593

Vandenbussche F, Petrasek J, Zadniková P, Hoyerová K, Pesek B, Raz V, Swarup R, Bennett M, Zazimalova E, Benkova E, Van Der Straeten D (2010) The auxin influxcarriers AUX1 and LAX3 are involved in auxin-ethylene interactions during apical hook development in Arabidopsis thaliana seedlings. Development 137: 597-606

Vierstra RD (2003) The ubiquitin/26S proteasome pathway, the complex last chapter in the life of many plant proteins. Trends Plant Sci 8: 135-142

35 Vernoud V, Horton AC, Yang Z, Nielsen E (2003) Analysis of the small GTPase gene superfamily of 36 arabidopsis. Plant Physiol 131:1191-1208 
Version définitive du manuscrit publié dans / Final version of the manuscript published in :

Physiologia Plantarum, 2014, 152(1), 184-201 http://dx.doi.org/10.1111/ppl.12158

1 Vestman D, Larsson E, Uddenberg D, Cairney J, Clapham D, Sundberg E, von Arnold S (2011)

2 Important processes during differentiation and early development of somatic embryos of Norway

3 spruce as revealed by changes in global gene expression. Tree Genet Genomes 7: 347-362

4 Vondráková Z, Cvikrová M, Eliášová K, Martincová O, Vágner M (2010) Cryotolerance in Norway

5 spruce and its association with growth rates, anatomical features and polyamines of embryogenic

$6 \quad$ cultures. Tree Physiol 30: 1335-1348

7 Winkel-Shirley B (2002) Biosynthesis of flavonoids and effects of stress. Current Opinion Plant Biol

8 5: $218-223$

9 Wiweger M, Farbos I, Ingouff M, Lagercrantz U, Von Arnold S (2003) Expression of Chia4-Pa

10 chitinase genes during somatic and zygotic embryo development in Norway spruce (Picea abies):

11 similarities and differences between gymnosperm and angiosperm class IV chitinases. J Exp Bot 54:

$12 \quad 2691-2699$

13 Yoshida T, Nishimura N, Kitahata N, Kuromori T, Ito T, Asami T, Shinozaki K, Hirayama T (2006.)

14 ABA-hypersensitive germination3 encodes a protein phosphatase 2C (AtPP2CA) that strongly

15 regulates abscisic acid signaling during germination among arabidopsis protein phosphatase 2Cs.

16 Plant Physiol 140: 115-126

17 Zhang Y, Zhang S, Han S, Li X, Qi L (2012) Transcriptome profiling and in silico analysis of somatic 18 embryos in Japanese larch (Larix leptolepis) Plant Cell Rep. 31: 1637-1657

19 Zhen Y, Zhao Z-Z, Zheng R-H, Shi J (2012) Proteomic analysis of early seed development in Pinus 20 massoniana L. Plant Physiol Biochem 54: 97-104 
Version définitive du manuscrit publié dans / Final version of the manuscript published in :

Physiologia Plantarum, 2014, 152(1), 184-201 http://dx.doi.org/10.1111/ppl.12158

\section{Supporting information}

2 Additional Supporting Information may be found in the online version of this article:

3

4

Appendix S1 Identification of differentially expressed transcripts in immature somatic embryos of 5 maritime pine matured for 1 week on either 4 or $9 \mathrm{~g} \mathrm{~L}^{-1}$ gellan gum.

6

Appendix S2 Functional annotation of assembled sequences (significant transcripts) based on gene ontology (GO) categorization.

Appendix S3 Representative 2-D PAGE map for proteins from immature somatic embryos of maritime pine matured for 1 week on high gellan gum $\left(9 \mathrm{~g} \mathrm{~L}^{-1}\right)$.

12

Appendix S4 Identification of differentially expressed proteins in immature somatic embryos of 14 15

Appendix S5 Assignment of the putative proteins identified in immature somatic embryos of 17 maritime pine matured for 1 week to functional categories, according to Blast2GO (http://www.blast2go.com/b2ghome). 
Version définitive du manuscrit publié dans / Final version of the manuscript published in :

Physiologia Plantarum, 2014, 152(1), 184-201 http://dx.doi.org/10.1111/ppl.12158

$$
1
$$

2 Table 1. Carbohydrate and protein content in maritime pine immature somatic embryos of 3 maritime pine matured for one week in the presence of either 4 or $9 \mathrm{~g} \mathrm{~L}^{-1}$ gellan gum.

$$
4
$$
5

6$$
7
$$
8 9

\section{Gellan gum concentration $\left(\mathrm{g} \mathrm{L}^{-1}\right)$}

Compound

$\left(\mu \mathrm{g} \mathrm{g}^{-1} \mathrm{DW}\right)^{*}$

49

$$
\begin{array}{rr}
27.44 \pm 2.22^{\mathrm{a}} & 17.27 \pm 1.39^{\mathrm{b}} \\
26.60 \pm 2.86^{\mathrm{a}} & 19.29 \pm 0.71^{\mathrm{b}} \\
6.88 \pm 0.14^{\mathrm{a}} & 8.29 \pm 1.24^{\mathrm{a}}
\end{array}
$$

Sucrose (Su)

$60.91 \pm 5.17^{\mathrm{a}}$

$$
44.85 \pm 2.65^{\mathrm{b}}
$$$$
\text { Ratio }(\mathrm{Fru}+\mathrm{Glu} / \mathrm{Su})
$$$$
7.9^{\mathrm{a}}
$$$$
4.4^{\mathrm{b}}
$$

Starch

$32.70 \pm 0.5^{\mathrm{a}}$

$46.30 \pm 0.92^{\mathrm{b}}$

$\underline{\text { Total protein }}$

$$
654.40 \pm 81.72^{\mathrm{a}} \quad 733.10 \pm 100.4^{\mathrm{a}}
$$

*Values are means of 3 (carbohydrates), 5 (total protein), or 6 (starch) measurements \pm confidence interval at the $5 \%$ error level. Within figure, different letters represent statistically significant differences 
Table 2: Characteristics of differentially expressed proteins in immature somatic embryos of maritime pine matured for 1 week on either 4 or $9 \mathrm{~g}$ $\mathrm{L}^{-1}$ gellan gum. Excised spot number refers to the spot marked in Fig. S2. The protein assignments and accession numbers were retrieved from the GenoToul database (http://genotoul-contigbrowser.toulouse.inra.fr:9092/Pinus_pinaster2/index.html) by the PEAKS identification engine. The most homologous protein in the UniProt database (http://www.uniprot.org/) and its species affiliation are given.

Gellan gum: protein relative abundance ( $9>4$ : protein over-expressed on $9 \mathrm{G}, 4>9$ : protein over-expressed on $4 \mathrm{G})$.

th: theoretical; exp : expected

\begin{tabular}{|c|c|c|c|c|c|c|c|}
\hline $\begin{array}{r}\text { Spot } \\
\text { number }\end{array}$ & Accession number & $\begin{array}{l}\text { Gellan } \\
\text { gum }\end{array}$ & Protein name & $\begin{array}{l}\text { UniProt } \\
\text { accession }\end{array}$ & Organism & $\begin{array}{l}\text { MW } \\
\text { th./exp. }\end{array}$ & $\begin{array}{l}\text { pHi } \\
\text { th./exp. }\end{array}$ \\
\hline 5 & SC_RP12A_ARATH.1.6 & $4>9$ & $\begin{array}{l}\text { 26S proteasome regulatory particle } \\
\text { subunit }\end{array}$ & Q0GEA1 & Camellia sinensis & $31 / 26.3$ & $4.95 / 4.96$ \\
\hline 56 & SC_STAD_RICCO.1.4 & $4>9$ & Acyl-[acyl-carrier-protein] desaturase & A9NVD4 & Picea sitchensis & $46.9 / 44.3$ & $5.65 / 5.5$ \\
\hline 36 & SC_00001024.1.1 & $4>9$ & Alanine aminotransferase & Q84UX4 & Oryza sativa & $53.6 / 52.3$ & $8.01 / 5.9$ \\
\hline 30 & SC_ADH3_SOLTU.1.15 & $4>9$ & Alcohol dehydrogenase & Q43025 & Pinus banksiana & $40.5 / 44.6$ & $6.12 / 6.02$ \\
\hline 34 & SC_ADH_FRAAN.16.30 & $4>9$ & Alcohol dehydrogenase & Q43025 & Pinus banksiana & $40.5 / 46.4$ & $6.12 / 5.86$ \\
\hline 32 & SC_00002407.1.1 & $4>9$ & $\begin{array}{l}\text { At5g54100 (Similarity to stomatin like } \\
\text { protein) }\end{array}$ & Q9LVW0 & A. thaliana & $43.6 / 47.2$ & $9.11 / 5.96$ \\
\hline 59 & SC_00001003.1.1 & $4>9$ & BAHD family acyltransferase, clade $\mathrm{V}$ & D8T9Y4 & S. moellendorffii & $49.4 / 55.4$ & $5.91 / 5.5$ \\
\hline 10 & SC_RRAA3_ARATH.2.3 & $4>9$ & Cell division protein FtsQ & A3TJS8 & Oryza sativa & $18 / 9.8$ & $5.6 / 5.7$ \\
\hline 55 & SC_CH62_CUCMA.1.9 & $4>9$ & Chaperonin CPN60-2, mito. & Q05046 & Cucurbita maxima & $57.6 / 52.7$ & $5.35 / 5.67$ \\
\hline 62 & SC_CH62_CUCMA.2.9 & $4>9$ & Chaperonin CPN60-2, mito. & Q05046 & Cucurbita maxima & $57.6 / 61.5$ & $5.35 / 5.47$ \\
\hline 27 & & & & & & & \\
\hline
\end{tabular}


$4>9 \quad$ Chaperonin CPN60-2, mito.

$4>9 \quad$ DEAD-box ATP-dependent

\section{Q05046 \\ RNA Q5VNM3 Oryza sativa} helicase 2

SC_MCM31_MAIZE.1.5

33 SC_EFTM_ARATH.1.6

45 SC_ENO1_HEVBR.7.31

58 SC_GLGS_ARATH.1.1

37 SC MDARS CUCSA.1.10

29 SC_LOC100274026_MAIZE.1.3

28 SC_PGKH1_ARATH.1.6

31 SC_PGKH1_ARATH.1.6

75 SC_PREP1_ARATH.1.3

50 SC_PDC2_ORYSI.1.19

51 SC_PDC2_ORYSI.1.19

52 SC_PDC2_ORYSI.3.19

53 SC_PDC2_ORYSI.3.19

44 SC_METK1_PICSI.34.55

46 SC_00154823.1.1

76 SC_DPE2_ARATH.1.1

\section{$4>9$} homolog 3

$4>9 \quad$ Elongation factor Tu. mito.

$4>9$ Enolase 1

$4>9$ Glucose-1-phosphate adenylyltransferase

$4>9$ Monodehydroascorbate reductase

$4>9 \quad$ NAD-dependent isocitrate dehydrogenase c

\section{4>9 Phosphoglycerate kinase}

$4>9$ Phosphoglycerate kinase

4>9 Presequence protease 1. chloro./mito.

$4>9$ Pyruvate decarboxylase isozyme 2

4>9 Pyruvate decarboxylase isozyme 2

4>9 Pyruvate decarboxylase isozyme 2

$4>9$ Pyruvate decarboxylase isozyme 2

4>9 S-adenosylmethionine synthase 1

4>9 UDP-glucose 6-dehydrogenase

9>4 4-alpha-glucanotransferase

\section{Q9ZT91 A. thaliana \\ Q9LEJ0 Picea sitchensis \\ B8LNV7 Picea sitchensis \\ A5JPK7 Vitis vinifera \\ Q6ZI55}

F4MKM1 Pinus pinaster

F4MKM1 Pinus pinaster

Q9LJL3

A2XFI3

A. thaliana

A2XFI3

Oryza sativa

Q10MW3 Oryza sativa

Q10MW3 Oryza sativa

A9NUH8 Picea sitchensis

Q6RK07 C. osmophloeum

DPE2 Q69Q02
$57.6 / 60.9 \quad 5.35 / 5.52$

$45.6 / 48.7 \quad 5.98 / 5.96$

$85.2 / 86$

$5.92 / 5.91$

$44.1 / 45.1 \quad 5.93 / 5.9$

$48.1 / 52.5 \quad 5.79 / 5.75$

$57.9 / 51.2 \quad 5.99 / 5.46$

$47.3 / 47.1 \quad 5.93 / 5.94$

$40.6 / 42.3 \quad 8.14 / 6.02$

$52.9 / 44.6 \quad 8.83 / 6.11$

$52.9 / 45 \quad 8.83 / 5.99$

$111.5 / 92 \quad 5.03 / 5.35$

$64.8 / 63.7 \quad 5.6 / 5.74$

$64.8 / 63.2 \quad 5.6 / 5.75$

$64.7 / 63 \quad 5.53 / 5.72$

$64.7 / 63.3 \quad 5.53 / 5.71$

$42.9 / 47.4 \quad 5.42 / 5.7$

$52.9 / 55.8 \quad 5.99 / 5.72$

$108.3 / 90 \quad 6 / 5.61$ 
43 SC_00000649.1.1

40 SC_00000578.1.1

42 SC_SAHH_NICSY.1.26

35 SC_ADH1_PETHY.12.16

6 SC_00003988.1.1

22 SC_00002431.1.1

70 SC_CALR_RICCO.2.19

69 SC_CALR_RICCO.2.19

49 SC_CH62_CUCMA.1.9

17 SC_00004509.1.1

64 SC 00000119.1.1

4 SC_GLGL1_BETVU.1.2

24 SC_00007308.1.1

47 SC_ILV5_SPIOL.1.21

9 SC_UMC2374_MAIZE.1.3

1 SC_PROF1_PHAVU.6.6
(Amylomaltase)

9>4 6-phosphogluconat

dehydrogenase. B9RVA7 Ricinus communis

$54.2 / 55.9$

$6.09 / 5.94$ decarboxylating

9>4 Acetyl-CoA carboxylase (Biotin O23960 Glycine max carboxylase)

9>4 Adenosylhomocysteinase

B8LLL7 Picea sitchensis

9>4 Alcohol dehydrogenase

9>4 AT3g23600/MDB19_9

9>4 Benzoquinone reductase

9>4 Calreticulin

$9>4 \quad$ Calreticulin

9>4 Chaperonin CPN60-2. mito.

Q43300 Pinus banksiana

Q9LUG8

A. thaliana

A3F7Q3 Picea sitchensis

Q9FYV2 Pinus taeda

Q9FYV2 Pinus taeda

9>4 Expansin S2

Q05046 Cucurbita maxima

Q39626 Cucumis sativus

9>4 FAM10 family protein At4g22670

Q93YR3 A. thaliana

9>4 Glucose-1-P adenylyltransferase subunit

9>4 GTP-binding nuclear protein Ran-A1

9>4 Ketol-acid reductoisomerase. chloro.

P41918 Nicotiana tabacum

O82043 Pisum sativum

9>4 Probable 6-phosphogluconolactonase

4. Q69NG5 Oryza sativa chloro.

$9>4 \quad$ Profilin
$52.3 / 57.6 \quad 5.82 / 6.11$

$53.2 / 55.8 \quad 5.75 / 5.96$

$40.4 / 47.3 \quad 5.76 / 5.82$

$25.9 / 23.4 \quad 5.17 / 5.12$

$21.7 / 21.4 \quad 5.94 / 6.17$

$49.6 / 50.1 \quad 4.6 / 4.84$

$49.6 / 0.4 \quad 4.6 / 4.86$

$57.6 / 60.6 \quad 5.35 / 5.75$

$25.4 / 21.2 \quad 9.39 / 6.02$

$46.6 / 57.5 \quad 4.83 / 5.31$

$57.7 / 32.9 \quad 6.05 / 4.76$

$25 / 23.8 \quad 6.38 / 6.12$

$57.8 / 61.7 \quad 5.85 / 5.84$

$28.3 / 23.8 \quad 5.65 / 5.34$

$14.3 / 6.1 \quad 4.61 / 4.81$ 

26 SC_00151055.1.1
27 SC_00151055.1.1
71 SC_PDI14_ARATH.1.13

$$
9>4
$$

$9>4$ Proteasome subunit beta type 1

$\mathrm{P} 42742$

A. thaliana

P42742

A. thaliana

9>4 Proteasome subunit beta type 1

A7KY78

Oldenlandia affinis

A7KY78 Oldenlandia affinis

9>4 Protein disulfide isomerase

\section{A9CPA7 Glycine max}

Q8VWV9 Pinus pinaster

9>4 Putative alpha-xylosidase

9>4 Putative expansin-B14

9>4 Putative germin-like protein 9-1

Q6H677 Oryza sativa

Q652Q1 Vitis vinifera

9>4 Superoxide dismutase

Q6QJL0 Pinus pinaster

9>4 Superoxide dismutase

A9NNA1 Picea sitchensis

9>4 Tubulin beta- 2 chain

Q9ZPN9 Eleusine indica

$\begin{array}{ll}40.3 / 42.3 & 9.46 / 6.19 \\ 40.3 / 42.8 & 9.46 / 6.14 \\ 54.6 / 70.9 & 5.1 / 4.98 \\ 54.6 / 73.5 & 5.1 / 4.98 \\ 47.7 / 53.9 & 5.41 / 5.58 \\ 100.6 / 91 & 6.1 / 6.09 \\ 25.5 / 27.2 & 5.3 / 5.97 \\ 23.5 / 22.4 & 6.4 / 6.21 \\ 28.6 / 21.1 & 7.18 / 5.89 \\ 25.5 / 20.4 & 8.7 / 6.08 \\ 50.4 / 54.8 & 4.71 / 5.15 \\ 22.5 / 25.4 & 5.79 / 5.19\end{array}$




\section{Figure legends:}

Fig.1. Viability and starch accumulation in immature somatic embryos of maritime pine matured on either $4 \mathrm{~g} \mathrm{~L}^{-1}$ or $9 \mathrm{gL}^{-1}$ gellan gum. Confocal images (projections of optical sections) of embryos stained with fluorescein diacetate and propidium iodide (PI) show green fluorescein fluorescence in viable cells and red fluorescence of PI -DNA complexes in dead cells (a-d). Light transmission microscope images show staining of starch grains with Lugol solution (e, f). (a) Very early embryos consisting of a few meristematic cells and 1 or 2 suspensor cells before transfer onto maturation media. (b) Embryo matured for 2 weeks on $4 \mathrm{~g}$ $\mathrm{L}^{-1}$ gellan gum with dead cells apparent in the meristem. (c) Embryo matured for 3 weeks on 4 $\mathrm{g} \mathrm{L}^{-1}$ gellan gum with the disorganized suspensor composed of short viable cells; dead cells were present throughout the suspensor structure. (d) Embryos matured for 3 weeks on $9 \mathrm{~g} \mathrm{~L}^{-1}$ gellan gum with well-organized suspensors consisting of long narrow viable cells; dead cells were present in the distal parts of suspensors. (e) Embryos matured for 2 weeks on $4 \mathrm{~g} \mathrm{~L}^{-1}$ gellan gum accumulated starch grains around nuclei and in the cytoplasm of suspensor cells. (f) Embryos matured for 2 weeks on $9 \mathrm{~g} \mathrm{~L}^{-1}$ gellan gum accumulated starch grains in suspensor cells and in the basal part of the embryo proper; a much greater extent of starch accumulation was evident. Scale bar $=100 \mu \mathrm{m}$ (a, b), $200 \mu \mathrm{m}$ (c, d, e, f); m - meristematic cells, s- suspensor cells.

Fig. 2. Morphological appearance of embryonal masses of maritime pine matured for 12 weeks on either $4 \mathrm{~g} \mathrm{~L}^{-1}$ (a) or $9 \mathrm{~g} \mathrm{~L}^{-1}$ (b) gellan gum. Note embryonal mass proliferation on $4 \mathrm{G}(\mathrm{a} 1, \mathrm{a} 2)$ and presence of cotyledonary somatic embryos on $9 \mathrm{G}(\mathrm{b} 1, \mathrm{~b} 2)$. Scale bar $=1 \mathrm{~cm}$ $(\mathrm{a} 1, \mathrm{~b} 1), 1 \mathrm{~mm}(\mathrm{a} 2, \mathrm{~b} 2)$.

Fig.3. Biological characteristics of immature somatic embryos of maritime pine during maturation in the presence of either low $\left(4 \mathrm{~g} \mathrm{~L}^{-1}, O\right)$ or high $\left(9 \mathrm{~g} \mathrm{~L}^{-1}, \mathbf{\square}\right)$ gellan gum. A, Fresh weight (FW); B, Dry weight (DW); C, Water content. Bars represent confidence interval at the $5 \%$ error level. Letters represent statistical groups defined by the Multiple Comparisons of Means method $(P<0.05, \mathrm{~N}=10)$.

Fig.4. Endogenous abscisic acid (ABA) content of immature somatic embryos of maritime pine during maturation in the presence of either low $\left(4 \mathrm{~g} \mathrm{~L}^{-1}, \bigcirc\right)$ or high $\left(9 \mathrm{~g} \mathrm{~L}^{-1}, \mathbf{\square}\right)$ gellan 
Version définitive du manuscrit publié dans / Final version of the manuscript published in :

Physiologia Plantarum, 2014, 152(1), 184-201 http://dx.doi.org/10.1111/ppl.12158

gum. Bars represent confidence interval at the 5\% error level. Letters represent statistical groups defined by the Multiple Comparisons of Means method $(P<0.05, \mathrm{~N}=10)$.

Fig.5. Gene ontology (Biological Process categories at level 2) terms found to be significantly enriched after 1 week of maturation with either low $\left(4 \mathrm{~g} \mathrm{~L}^{-1}, \square\right)$ or high $\left(9 \mathrm{~g} \mathrm{~L}^{-1}, \boldsymbol{\square}\right)$ gellan gum. Only GO categories for which $>5$ genes were represented are included. To test whether Gene Ontology terms were enriched in a test group, when compared to a reference group, Fisher's Exact Test with Multiple Testing Correction of FDR (FDR $<0.05$, Benjamini and Hochberg, 1995) was used.

Numbers of sequences: Numbers of sequences involved in each biological process. 
Fig.1
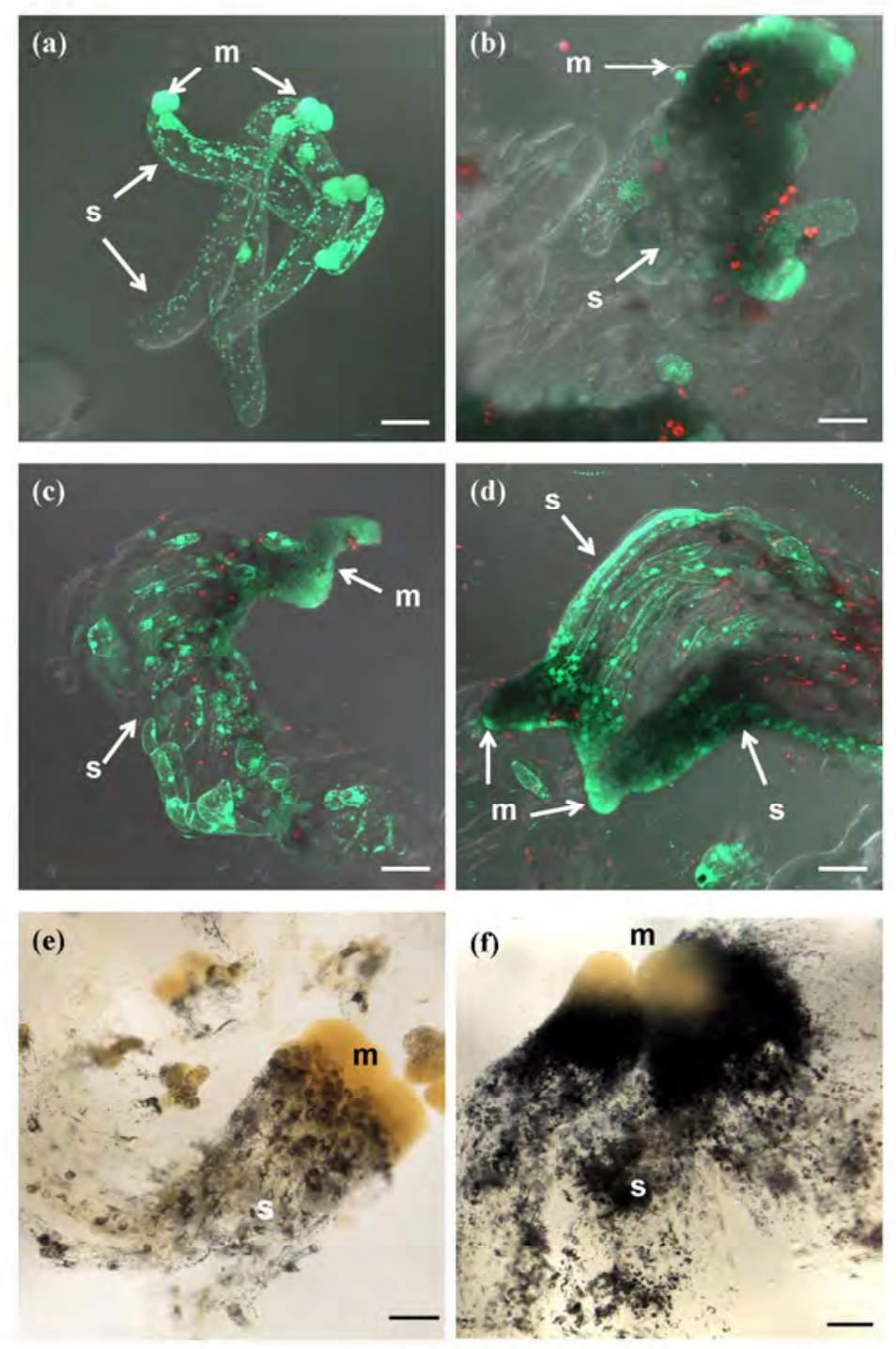

Viability and starch accumulation in immature somatic embryos of maritime pine matured on either $4 \mathrm{~g} \mathrm{L-1}$ or $9 \mathrm{gL}-1$ gellan gum. Confocal images (projections of optical sections) of embryos stained with fluorescein diacetate and propidium iodide (PI) show green fluorescein fluorescence in viable cells and red fluorescence of PI -DNA complexes in dead cells (a-d). Light transmission microscope images show staining of starch grains with Lugol solution (e,f). (a) Very early embryos consisting of a few meristematic cells and 1 or 2 suspensor cells before transfer onto maturation media. (b) Embryo matured for 2 weeks on $4 \mathrm{~g} \mathrm{L-1}$ gellan gum with dead cells apparent in the meristem. (c) Embryo matured for 3 weeks on $4 \mathrm{~g} \mathrm{~L}-1$ gellan gum with the disorganized suspensor composed of short viable cells; dead cells were present throughout the suspensor structure. (d) Embryos matured for 3 weeks on $9 \mathrm{~g} \mathrm{~L}-1$ gellan gum with well-organized suspensors consisting of long narrow viable cells; dead cells were present in the distal parts of suspensors. (e) Embryos matured for 2 weeks on $4 \mathrm{~g} \mathrm{~L}-1$ gellan gum accumulated starch grains around nuclei and in the cytoplasm of suspensor cells. (f) Embryos matured for 2 weeks on $9 \mathrm{~g} \mathrm{~L}-1$ gellan gum accumulated starch grains in suspensor cells and in the basal part of the embryo proper; a much greater extent of starch 
Version définitive du manuscrit publié dans / Final version of the manuscript published in :

Physiologia Plantarum, 2014, 152(1), 184-201 http://dx.doi.org/10.1111/ppl.12158

accumulation was evident. Scale bar $=100 \mu \mathrm{m}(\mathrm{a}, \mathrm{b}), 200 \mu \mathrm{m}(\mathrm{c}, \mathrm{d}, \mathrm{e}, \mathrm{f}) ; \mathrm{m}-$ meristematic cells, s suspensor cells.

$190 \times 275 \mathrm{~mm}(220 \times 220$ DPI $)$ 
Version définitive du manuscrit publié dans / Final version of the manuscript published in :

Physiologia Plantarum, 2014, 152(1), 184-201 http://dx.doi.org/10.1111/ppl.12158
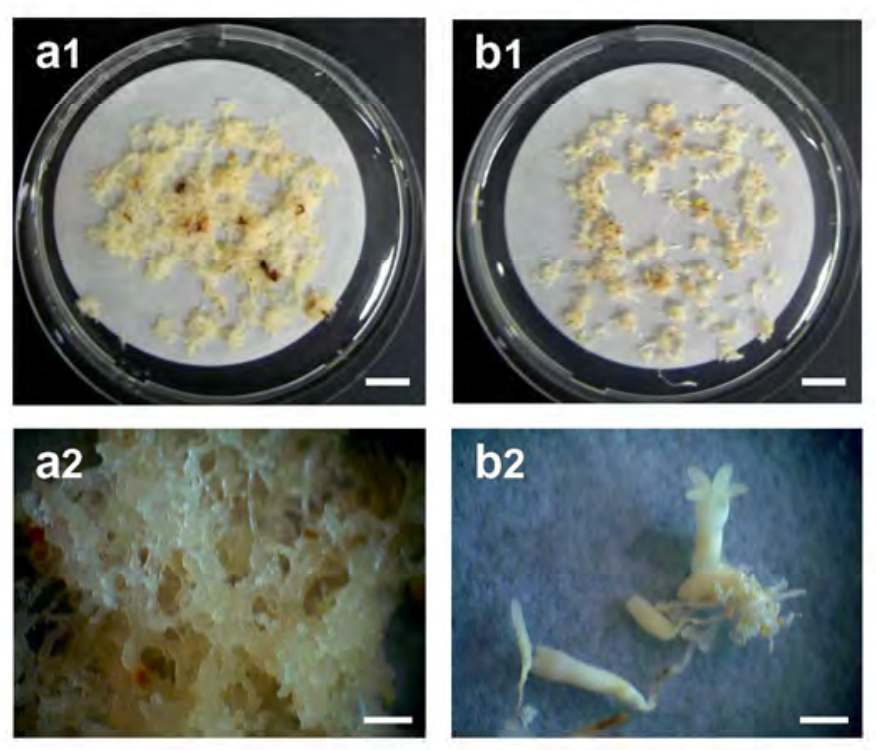

Morphological appearance of embryonal masses of maritime pine matured for 12 weeks on either $4 \mathrm{~g} \mathrm{L-1}$ (a) or $9 \mathrm{~g} \mathrm{L-1}$ (b) gellan gum. Note embryonal mass proliferation on 4G (a1, a2) and presence of cotyledonary somatic embryos on $9 \mathrm{G}(\mathrm{b} 1, \mathrm{~b} 2)$. Scale bar $=1 \mathrm{~cm}(\mathrm{a} 1, \mathrm{~b} 1), 1 \mathrm{~mm}(\mathrm{a} 2, \mathrm{~b} 2)$.

$190 \times 275 \mathrm{~mm}(223 \times 224 \mathrm{DPI})$ 
Version définitive du manuscrit publié dans / Final version of the manuscript published in : Physiologia Plantarum, 2014, 152(1), 184-201 http://dx.doi.org/10.1111/ppl.12158
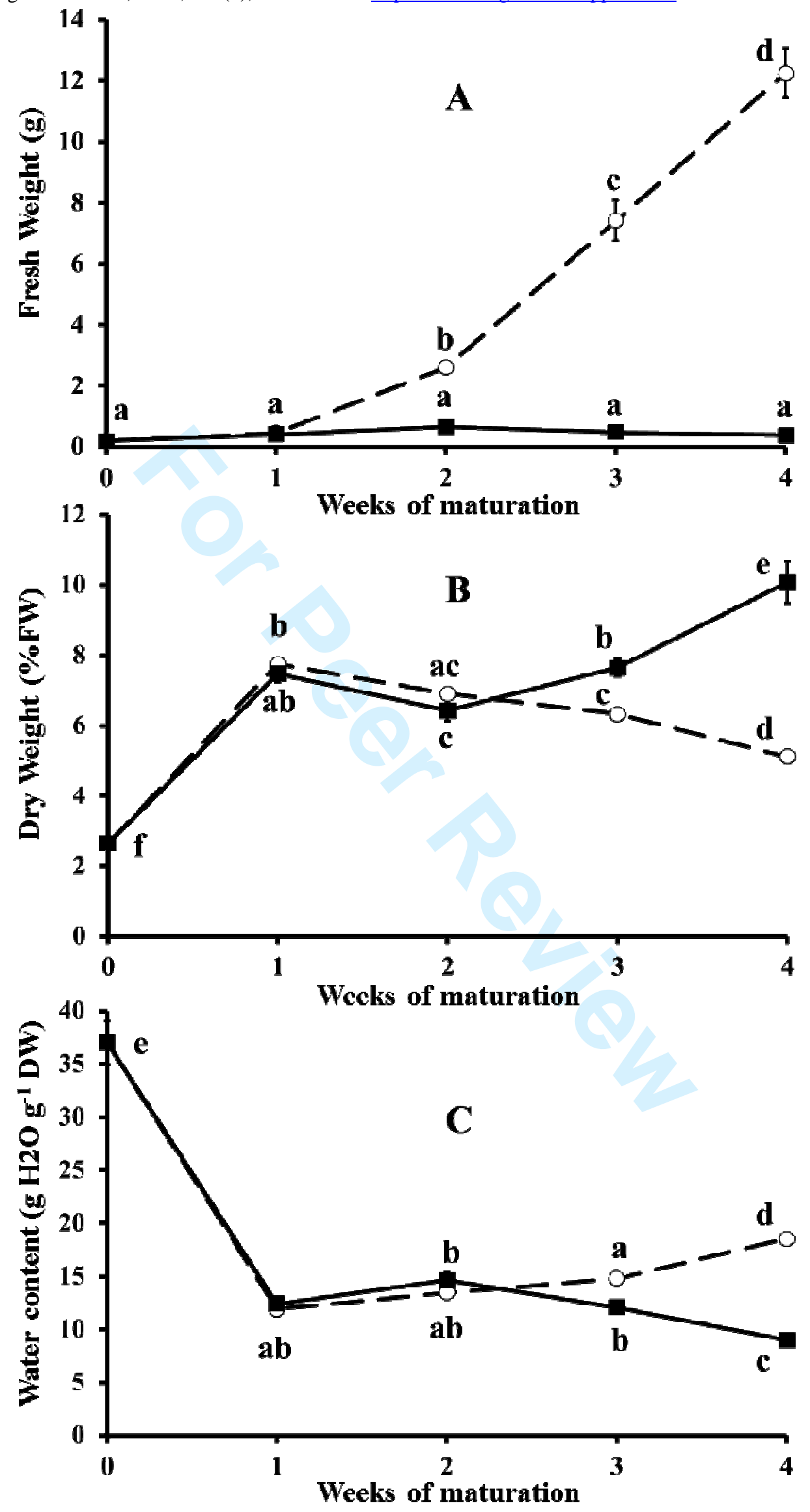

Figure 3. 
Version définitive du manuscrit publié dans / Final version of the manuscript published in :

Physiologia Plantarum, 2014, 152(1), 184-201 http://dx.doi.org/10.1111/ppl.12158

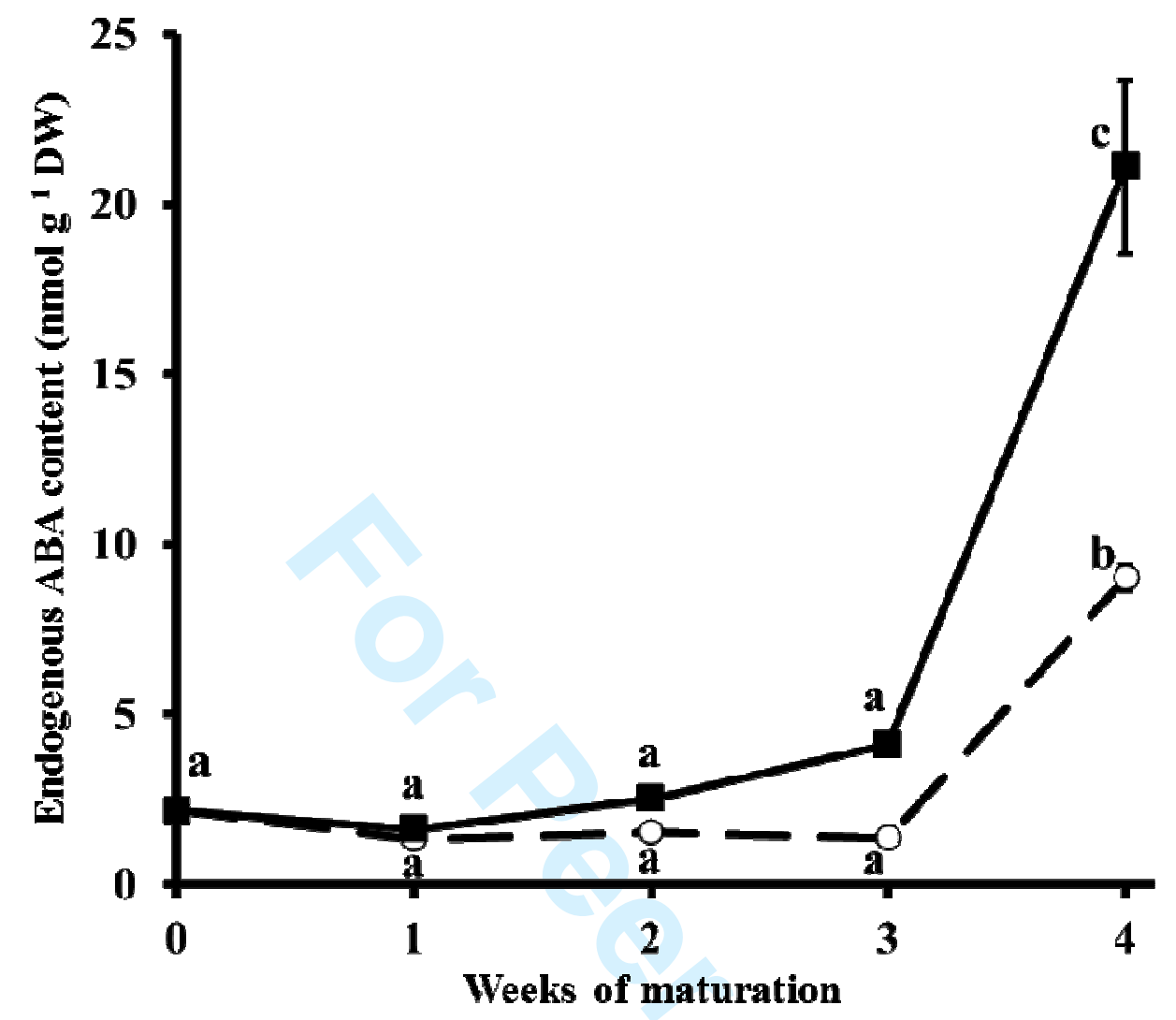

Figure 4 
Version définitive du manuscrit publié dans / Final version of the manuscript published in : Physiologia Plantarum, 2014, 152(1), 184-201 http://dx.doi.org/10.1111/ppl.12158

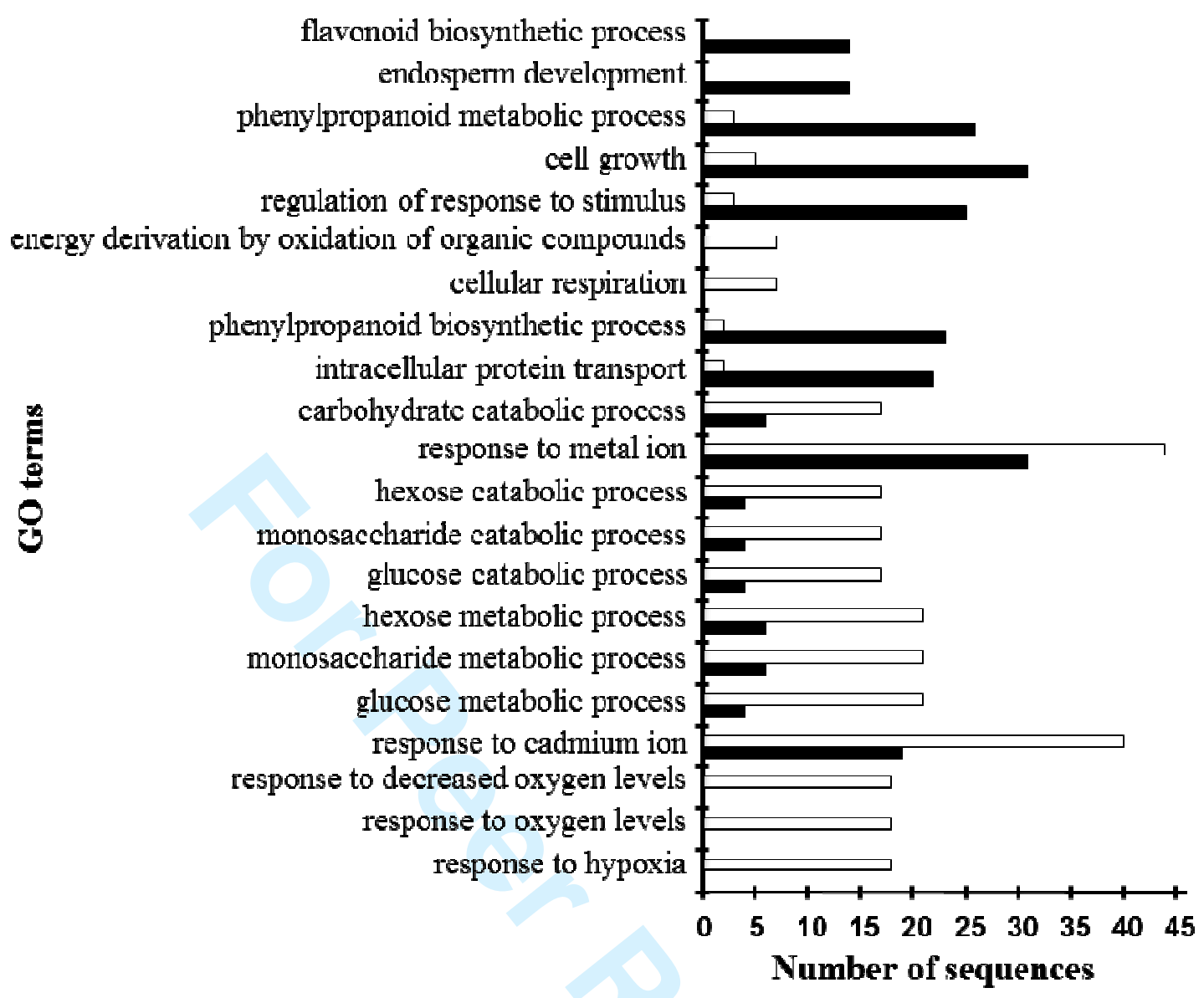

Figure 5. 